NBER WORKING PAPER SERIES

\title{
HISTORICAL PERSPECTIVES ON FINANCIAL DEVELOPMENT AND ECONOMIC GROWTH
}

\author{
Peter L. Rousseau \\ Working Paper 9333 \\ http://www.nber.org/papers/w9333
}
NATIONAL BUREAU OF ECONOMIC RESEARCH
1050 Massachusetts Avenue
Cambridge, MA 02138
November 2002

The views expressed herein are those of the authors and not necessarily those of the National Bureau of Economic Research.

(C) 2002 by Peter L. Rousseau. All rights reserved. Short sections of text, not to exceed two paragraphs, may be quoted without explicit permission provided that full credit, including (C) notice, is given to the source. 
Historical Perspectives on Financial Development and Economic Growth

Peter L. Rousseau

NBER Working Paper No. 9333

November 2002

JEL No. E44, G10, N11, N21

\section{ABSTRACT}

This paper uses standard tools of empirical macro economics to examine how well the existing historical time series support a role for financial factors in real sector activity in four economies that experienced what are widely considered to be "financial revolutions" over the past 400 years. The evidence presented for the Dutch Republic (1600-1794), England (1700-1850), the United States (17901850), and Japan (1880-1913) suggests that the emergence of financial instruments, institutions, and markets played a central role in promoting trade, commerce, and industrialization. Cross- section regressions with a wider set of countries for the post-1850 period offer additional support for the Schumpeterian view of finance in growth. Though limitations of the available data argue for a cautious interpretation, the findings are consistent with the traditional and more descriptive analyses of these events in the economic history literature, and with results obtained for the post-1960 period by modern macro economists.

Peter L. Rousseau

Department of Economics

Vanderbilt University

Box 1819 Station B

Nashville, TN 37235

and NBER

peter.1.rousseau@vanderbilt.edu 
The link between financial development and economic growth is not a recent discovery. And though Bagheot (1873), Schumpeter (1911), and Gurley and Shaw (1955) motivated this relationship decades, and indeed, over a century ago, it remained for economic historians such as Davis (1965), Cameron (1967), and Sylla (1969), among others, to give empirical content to the idea. These scholars primarily used the historical experiences of England and the United States to illustrate the role of the financial system in the path to market leadership. Since then, macro and development economists have studied the hypothesis more formally with theoretical models in which countries achieve rapid growth through well-developed financial systems that reduce credit market frictions (e.g., Greenwood and Jovanovic, 1990, and Greenwood and Smith, 1997), and with cross-country and time series statistical studies that uncover significant effects of financial sector size on macroeconomic outcomes (e.g., King and Levine, 1993, and Rousseau and Wachtel, 1998). ${ }^{1}$

Interestingly, economic historians and macro economists seem for the most part content to pursue their respective agendas independently. Perhaps this is because macro economists usually ask whether financial factors do indeed matter for growth, while most economic historians see the answer to this question as more obvious, and ask instead how much they matter. The economic historian's prior is understandable - older case studies have made powerful arguments for financeled growth with the sporadic data observations that are usually available. For the macro economist, however, the lack of an explicit role for financial factors in the baseline neoclassical growth model combines with a recognition of the statistical and conceptual problems of establishing causation in cross-country and time series regressions to yield a more cautious perspective. This article attempts to narrow the gap between these views by illustrating with standard macro-econometric techniques

\footnotetext{
${ }^{1}$ The empirical literature on the so-called "finance-growth nexus" has expanded rapidly in recent years, making an exhaustive list of references impractical to provide here. Levine (1997) offers a useful survey.
} 
that the historical time series that are available for Amsterdam (1640-1794), England (1720-1850), the United States (1790-1850), and Meiji Japan (1880-1913) are consistent with the "finance-led" growth hypothesis.

The approach is decidedly macro economic. This is because I believe that the empirical growth literature has under-emphasized a key mechanism through which finance matters in the early stages of economic development - resource mobilization. This is not to say that banks and financial markets do not also promote growth by directing resources to productive uses, but that the ability to overcome project indivisibilities is the first bottleneck through which a young economy must pass. This turns out to be important for the four countries considered in this study, and especially for the Netherlands, England, and the United States, whose financial sectors emerged during their "preindustrial" epochs. Is it no coincidence that England, with the key components of a financial system in place by 1750 , was poised to tackle industrialization next? The main findings suggest that banks and financial markets did promote investment and commercial activities by generating information, pooling funds, facilitating payments, and providing working capital for the largest companies that traded on the world's earliest "stock exchanges," at least in the modern sense of the term.

The article proceeds on a case-by-case basis, but will, to the degree that it is practical, offer a consistent empirical framework throughout. At the end, I summarize some of my recent findings with Richard Sylla for a larger group of countries after 1850. It seems only appropriate to begin the analysis with the Netherlands, the site where the action begins.

\section{AMSTERDAM}

\subsection{The World's First Financial Revolution?}

Amsterdam rose to prominence as a commercial city in the late 16th century. Its strategic position in the North Sea for intra-European and Baltic trade made it a logical heir to the inheritance 
of Antwerp, which had been the center of European commerce over the preceding century (van der Wee, 1963). As the largest city in the newly-formed United Provinces under Habsburg rule, Amsterdam's reputation for ethnic tolerance also drew immigrants and their capital from the rest of Europe and the Eastern Mediterranean. These factors combined by the early 17th century to produce a bustling commercial community. As the potential for speculation and profit in trading with the East Indies became increasingly clear, Amsterdam merchants began pooling resources to equip individual voyages, with the profits distributed upon sale of the incoming cargoes. These arrangements were formalized in 1602 with the chartering of the United East India Company (or VOC, short for Vereenigde Oostindische Compagnie). The charter called for a combine from six cities, or chambers, of which Amsterdam was by far the largest and most important. The VOC was capitalized with 2,167 shares at a par value of $3,000 \mathrm{fl}$. each, and the owners could liquidate their stakes through the Company once every ten years (Glamann, 1958, pp. 7-8). But when the Directors repudiated this provision at the end of the first decade, those wishing to liquidate needed a secondary market. It was in this climate that shares and futures began to trade on the Amsterdam bourse - the world's first modern securities market if we are to believe the engaging anecdotes of Joseph de la Vega (1688).

The VOC was Amsterdam's largest trading company and held a monopoly by statute and in practice on Asiatic trade east of the Cape of Good Hope, but other forms of commerce, especially intra-European, also flourished in Amsterdam throughout the 17th century. It was decided early on that the city would need a clearinghouse for exchange, and the Bank of Amsterdam got started in 1602 to perform this function. And though the innovations of a clearing bank and exchange bills did not originate in Amsterdam, having existed previously in Venice and Antwerp, never before had either form been used so successfully.

The Bank of Amsterdam (BA) was not a bank of issue, but instead accepted bullion and coin 
from merchants and held them for safekeeping, issuing receipts for "drawing accounts" that could be used for exchanging wealth as needed in the course of trade. The Bank also made large loans to the VOC and to the government over the next two centuries (to the latter for waging wars), but otherwise limited its discounting activities to trade bills. According to de la Vega, however, the Bank did not only support commodity trades, but also trades of stock. It was in this manner that the Bank was a key component of the stock exchange.

\subsection{Data and Methodology}

To explore quantitatively the relationship between finance and growth in pre-Industrial Amsterdam, some measures of commercial investment and of financial size and efficiency are needed. And though there are few continuous time series from the period, there are enough to conduct a preliminary statistical investigation. Van Dillen (1934, pp. 117-123), for example, published annual figures for the Bank of Amsterdam's activities from 1610 through 1820, including the balances in its "drawing" accounts and loans to the VOC. To the extent that the BA supported the stock market and commerce in Amsterdam during this period, the size of its drawing accounts may be a reasonable measure of the city's financial development. Further, Neal (1990) has improved upon van Dillen's (1931) share price series for the VOC from 1723 through $1794 .{ }^{2}$ I will use these data to explore the efficiency of the Amsterdam market and the importance of any financing constraints that the VOC might have faced. Measures of aggregate investment in the city are not generally available, but the VOC archives do include the number of voyages that the Company sent

\footnotetext{
${ }^{2}$ To build the annual series, I use the final price observation in each year for VOC shares from Neal's reading of the Amsterdam Courant. These observations are usually from the last week in December. I use the final price observations from van Dillen (1931) for years that are unavailable in Neal's data. The VOC prices and other stock market data from Neal (1990) are available on the world-wide web from the Inter-University Consortium for Political and Social Research (ICPSR) at the address http://www.icpsr.umich.edu.
} 


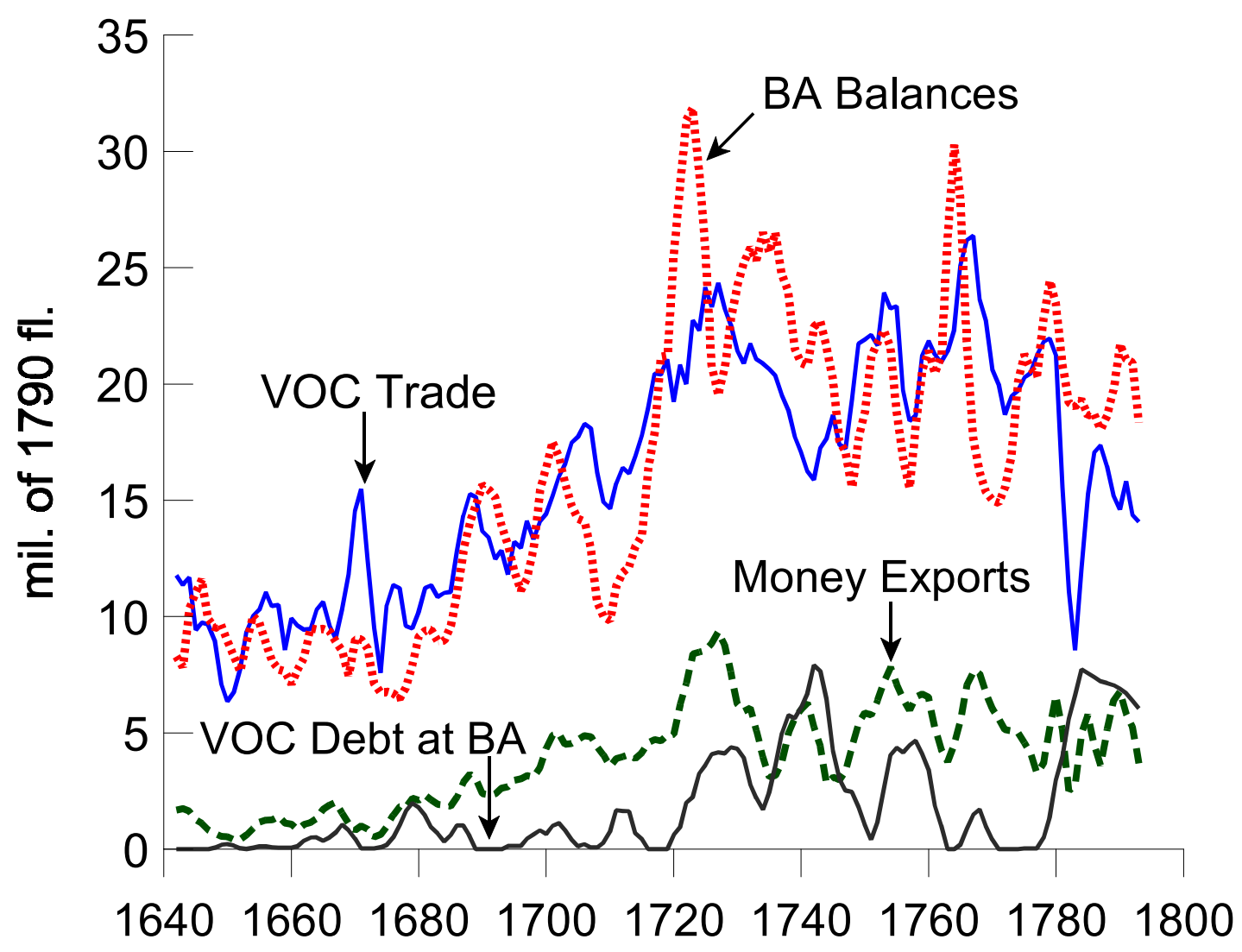

Figure 1. Finance and Trade Quantities, Amsterdam, 1641-1794.

to the East Indies in each year from 1641 to 1794, the amounts of gold, silver, and coins that left with these voyages, and the market values of their incoming cargoes. ${ }^{3}$ If investment and trading activity in the VOC reflect commercial activity in Amsterdam more broadly, testing for statistical links between drawing balances at the BA and VOC investment might shed some light on how finance affected real activity at the time. Figure 1 shows the evolution of the florin-denominated real quantities as 3-year moving averages. ${ }^{4}$ Even casual examination of Fig. 1 indicates that the market value of VOC trade,

\footnotetext{
${ }^{3}$ The number of outgoing VOC voyages is from the Netherlands Historical Data Archive's (NHDA) Data Set D0100 titled "Dutch-Asiatic shipping, 1602-1795." The data are similar but not identical to those presented in Bruin, Gaastra, and Schoffer (1987). Eastbound money shipments are from NHDA Data Set F3503 titled "Total amounts of money, 1603-1795." The market value of VOC trade is from NHDA Data Set No. F3505 titled "Returning ships and products, 1641-1796."

${ }^{4}$ The long-run movement of VOC voyages tracks VOC trade closely with a correlation coefficient of 0.69 . The index used to deflate florin-denominated quantities is van Zanden's (2000)
} 
hard money exports by the VOC, and the size of drawing account balances at the BA all saw dramatic increases following the financial crisis of 1672 until the mid-1720's - increases that were sustained until the decline of the VOC after 1780.

The vector autoregressive (VAR) approach facilitates investigation of dynamic interactions in stationary multivariate systems without imposing a priori structural restrictions. This type of exploration seems most appropriate for historical studies of finance and growth due to limitations of the available data. For example, to investigate the relationship between, say, the market value of VOC trade, drawing balances at the Bank of Amsterdam, and the value of money shipments to the East, a VAR would include a separate regression for each variable in the system on its own lags and those of the other variables:

$$
\begin{aligned}
& x_{1, t}=a_{1,0}+\sum_{i=1}^{k} a_{1, i} x_{1, t-i}+\sum_{i=1}^{k} b_{1, i} x_{2, t-i}+\sum_{i=1}^{k} c_{1, i} x_{3, t-i}+u_{1, t} \\
& x_{2, t}=a_{2,0}+\sum_{i=1}^{k} a_{2, i} x_{1, t-i}+\sum_{i=1}^{k} b_{2, i} x_{2, t-i}+\sum_{i=1}^{k} c_{2, i} x_{3, t-i}+u_{2, t} \\
& x_{3, t}=a_{3,0}+\sum_{i=1}^{k} a_{3, i} x_{1, t-i}+\sum_{i=1}^{k} b_{3, i} x_{2, t-i}+\sum_{i=1}^{k} c_{3, i} x_{3, t-i}+u_{3, t}
\end{aligned}
$$

where $x_{1}$ is trade, $x_{2}$ is drawing balances, $x_{3}$ is money shipments, and $k$ is the number of lags.

Stationarity of a VAR is important in interpreting tests for Granger non-causality, that is the hypothesis that past values of a variable do not jointly improve one-step ahead forecasts of another. Specifically, the null hypothesis implies the following joint restrictions on the coefficients in (1):

$$
\hat{l}_{j, i}=\hat{l}_{j, i+1}=\ldots=\hat{l}_{j, k}=0 \quad l=a, b, c ; j=1,2,3 .
$$

In general, the distributions of these tests are nonstandard when a VAR contains variables with unit

consumption price index for the Western Netherlands. 
roots, and differencing is usually required to ensure stationarity. Sims, Stock, and Watson (1990) show, however, that Granger tests conform to standard distributions in tri-variate VARs with unit roots so long as a cointegrating relationship exists among the variables. I apply this result in the eight tri-variate systems for Amsterdam because the null hypothesis of a unit root is not rejected with standard tests for any of the variables and there appears to be cointegrating relationship in each system. ${ }^{5}$ Running a VAR in levels is advantageous because it allows joint evaluation of short and long-term effects of movements in one variable upon others in the system.

Granger-causality tests must be interpreted cautiously, of course, since rejection of the block exclusion restrictions do not necessarily imply "economic causality." This is because the validity of the test is predicated on the inclusion of the full information set in the VAR. Since this condition is violated in any finite regression framework, especially when the available data do not precisely reflect the desired theoretical constructs, the results presented below are only suggestive of the nature of linkages between finance and investment in pre-Industrial Amsterdam.

When an investigator can specify a reasonable causal ordering for the variables in a VAR system (based on economic theory and perhaps the results of Granger tests), the nonlinear responses of each variable to one-time shocks in the others can be traced through time. This facilitates an evaluation of the economic importance (i.e., size) of the estimated effects, and for this reason I augment the results of Granger-causality tests with an examination of selected impulse responses.

\subsection{Finance and VOC Investment}

Table 1 presents estimates from four VARs that cover the period from 1641 to 1794 . The starting year is that in which all data become continuously available, and the end date was chosen to capture the decline of the United Provinces but not the period of political upheaval that surrounded

\footnotetext{
${ }^{5}$ See the Appendix for details about tests for unit roots and cointegration.
} 
Table 1

VAR models of financial quantities and VOC activity, Amsterdam 1641-1794

\begin{tabular}{|c|c|c|c|c|c|c|c|c|c|}
\hline Eq. & $\begin{array}{l}\text { Mkt. value } \\
\text { VOC trade } \\
\end{array}$ & $\begin{array}{c}\text { BA drawing } \\
\text { balances }\end{array}$ & $\begin{array}{c}\text { VOC money } \\
\text { exports }\end{array}$ & Adj. $\mathrm{R}^{2}$ & Eq. & $\begin{array}{c}\text { \# VOC } \\
\text { voyages }\end{array}$ & $\begin{array}{c}\text { BAdrawing } \\
\text { balances }\end{array}$ & $\begin{array}{c}\text { VOC money } \\
\text { exports }\end{array}$ & Adj. $\mathrm{R}^{2}$ \\
\hline $1 \mathrm{a}$ & $\begin{array}{c}0.402 \\
(0.000)\end{array}$ & $\begin{array}{c}0.204 \\
(0.007)\end{array}$ & $\begin{array}{c}0.134 \\
(0.061)\end{array}$ & 0.663 & $1 \mathrm{a}$ & $\begin{array}{c}0.405 \\
(0.003)\end{array}$ & $\begin{array}{c}0.245 \\
(0.082)\end{array}$ & $\begin{array}{c}0.011 \\
(0.228)\end{array}$ & 0.340 \\
\hline $1 b$ & $\begin{array}{c}0.041 \\
(0.662)\end{array}$ & $\begin{array}{c}0.799 \\
(0.000)\end{array}$ & $\begin{array}{c}0.061 \\
(0.373)\end{array}$ & 0.806 & $1 \mathrm{~b}$ & $\begin{array}{c}0.097 \\
(0.268)\end{array}$ & $\begin{array}{c}0.778 \\
(0.000)\end{array}$ & $\begin{array}{c}0.062 \\
(0.303)\end{array}$ & 0.809 \\
\hline $1 \mathrm{c}$ & $\begin{array}{l}-0.032 \\
(0.551)\end{array}$ & $\begin{array}{c}0.318 \\
(0.010)\end{array}$ & $\begin{array}{c}0.795 \\
(0.000)\end{array}$ & 0.693 & $1 \mathrm{c}$ & $\begin{array}{c}0.438 \\
(0.119)\end{array}$ & $\begin{array}{c}0.163 \\
(0.043)\end{array}$ & $\begin{array}{c}0.733 \\
(0.000)\end{array}$ & 0.701 \\
\hline Eq. & $\begin{array}{l}\text { Mkt. value } \\
\text { VOC trade }\end{array}$ & $\begin{array}{c}\text { BA drawing } \\
\text { balances }\end{array}$ & $\begin{array}{c}\text { VOC debt } \\
\text { at BA }\end{array}$ & Adj. $R^{2}$ & Eq. & $\begin{array}{c}\text { \# VOC } \\
\text { voyages }\end{array}$ & $\begin{array}{c}\text { BA drawing } \\
\text { balances }\end{array}$ & $\begin{array}{c}\text { VOC debt } \\
\text { at BA } \\
\end{array}$ & Adj. $R^{2}$ \\
\hline $1 \mathrm{a}$ & $\begin{array}{c}0.691 \\
(0.000)\end{array}$ & $\begin{array}{c}0.195 \\
(0.000)\end{array}$ & $\begin{array}{l}-0.054 \\
(0.463)\end{array}$ & 0.718 & $1 \mathrm{a}$ & $\begin{array}{c}0.420 \\
(0.008)\end{array}$ & $\begin{array}{c}0.397 \\
(0.021)\end{array}$ & $\begin{array}{c}0.046 \\
(0.466)\end{array}$ & 0.315 \\
\hline $1 b$ & $\begin{array}{c}0.218 \\
(0.094)\end{array}$ & $\begin{array}{c}0.729 \\
(0.000)\end{array}$ & $\begin{array}{c}0.185 \\
(0.046)\end{array}$ & 0.791 & $1 b$ & $\begin{array}{c}0.132 \\
(0.037)\end{array}$ & $\begin{array}{c}0.791 \\
(0.000)\end{array}$ & $\begin{array}{c}0.019 \\
(0.271)\end{array}$ & 0.794 \\
\hline $1 \mathrm{c}$ & $\begin{array}{l}-0.031 \\
(0.141)\end{array}$ & $\begin{array}{c}0.059 \\
(0.056)\end{array}$ & $\begin{array}{c}0.840 \\
(0.000)\end{array}$ & 0.868 & $1 \mathrm{c}$ & $\begin{array}{c}-0.006 \\
(0.012)\end{array}$ & $\begin{array}{c}0.040 \\
(0.118)\end{array}$ & $\begin{array}{c}0.866 \\
(0.000)\end{array}$ & 0.873 \\
\hline
\end{tabular}

NOTE: Equation numbers correspond to those in the text. Each VAR uses three lags. The VARs in the upper panels are in real log levels; in the lower panel they are in real levels due to zero values for VOC debt in some years. The table reports the sum of the regression coefficients for each variable block, with the significance level of the F-test for Granger non-causality in parentheses beneath the coeffcient sums. The dependent variables for equations (1a), (1b), and (1c) are the respective column headings from left to right. For example, in the VAR reported in the upper left panel, the dependent variable for equation (1a) is the market value of VOC trade; the total of Bank of Amsterdam drawing account balances is the dependent variable for equation (1b); VOC exports of hard money is the dependent variable in (1c). 
the French invasion of 1795 . Nested likelihood ratio tests select three lags. ${ }^{6}$ For each system, I report the sum of the regression coefficients on the variable blocks listed in the column headings in equations (1a)-(1c) along with the significance level of the F-test for block exclusion. In the upper left panel, for example, the results for equation (1a) indicate that the log of real drawing balances at the BA Granger-cause the real market value of VOC trade at the 1 percent level, while real money exports Granger-cause trade at the 6 percent level. The coefficients on the lag variables sum to a positive number for each of these blocks. Equation (1b) shows that neither trade nor money shipments Granger-cause BA drawing balances, while equation (1c) shows that BA balances Granger-cause money shipments. The results are qualitatively in the upper-right panel of the table, where the log of outgoing VOC voyages replaces VOC trade as the measure of investment, though money shipments are no longer statistically significant in equation (1a). These findings suggest that increases in the size of the BA's drawing account balances did indeed have a positive effect on commercial activity. Further, larger balances increased the amount of hard money that was used in conducting VOC business. This seems reasonable, as more resources at the disposal of the Bank would make it easier to meet demands for bullion prior to ship departures. There is no evidence of feedback from either trade or investment to drawing account balances or money exports. Thus, the effects of the financial variables appear to be unidirectional.

Figure 2 shows the impulse responses. The Granger-causality tests in Table 1 suggest that placing drawing account balances first, money exports second, and either investment or trade third would move from the most "exogenous" variable to the least. In panels (a) and (b), a 1 percent change in BA balances is related to an increase in VOC trade of about 0.45 percent after two years and a sharp increase in VOC voyages of about 0.3 percent. Both effects decay slowly. Evaluated at

\footnotetext{
${ }^{6}$ This method starts with a sufficiently large lag length and then tests successively that the coefficients on the final lag are zero, stopping when the restrictions are rejected.
} 


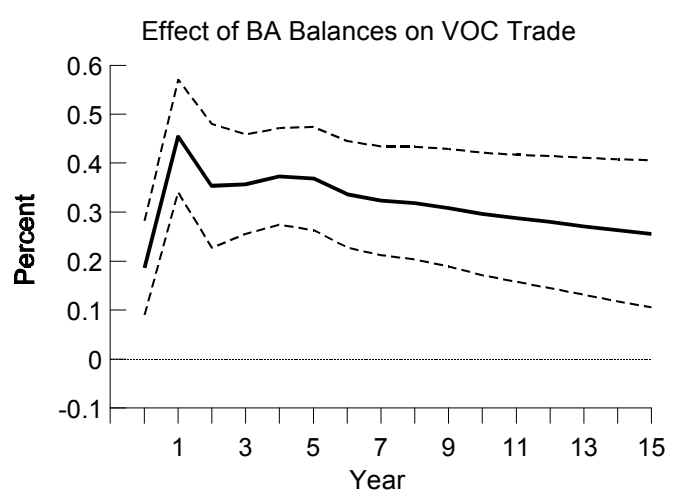

(a)

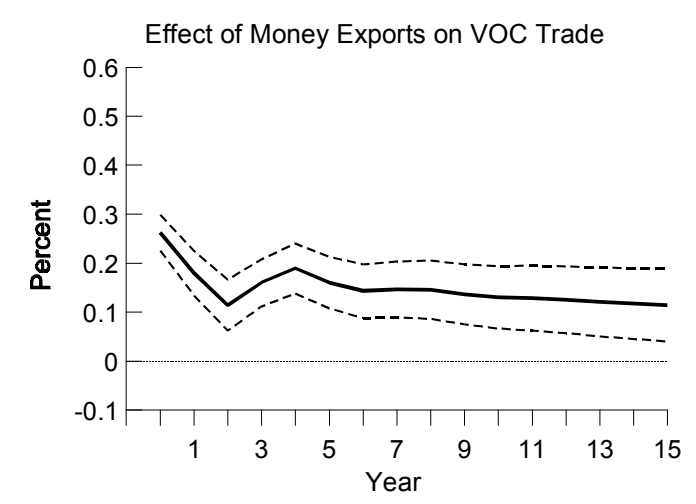

(c)

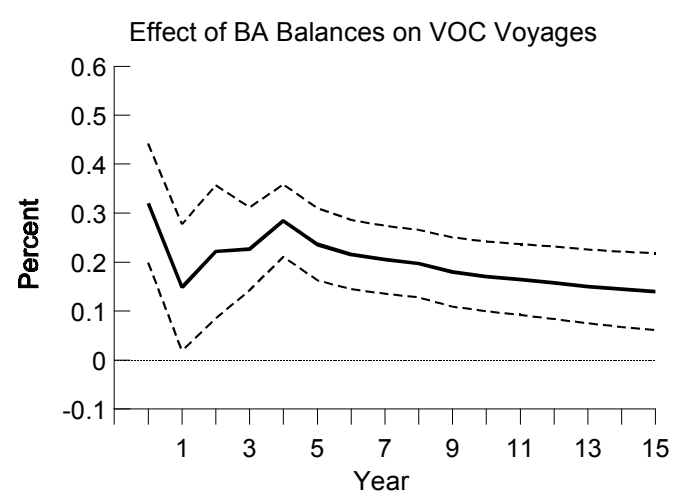

(b)

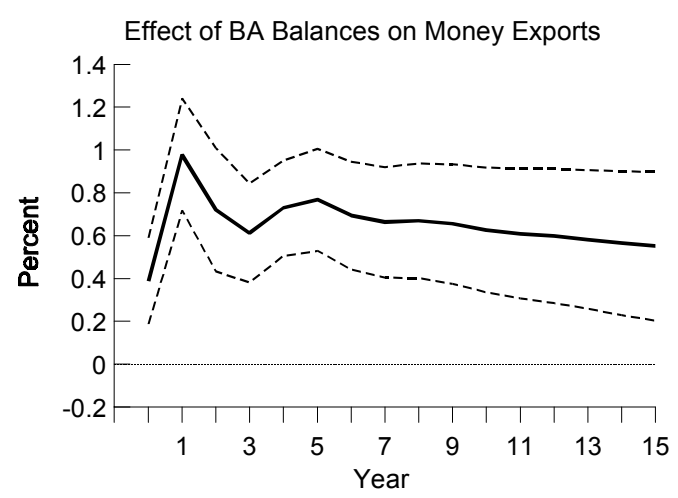

(d)

Figure 2. Selected impulse responses from VARs for Amsterdam, 1641-1794.

Note: The impulse responses are taken from the VARs reported in the upper panels of Table 1. Each plot traces the percent change in the affected variable that results over a fifteen-year horizon from a 1 percent change in the orthogonalized innovation to the potentially causal variable. The ordering is BA balances first, VOC hard money exports second, and either the market value of VOC trade or the number of VOC voyages third. Using Monte Carlo integration, the solid lines are the mean responses that result from 10,000 random draws from the distribution of the estimated VAR coefficients. The dotted lines are one standard error bands.

the sample means, the responses imply that increasing BA balances by 1.6 mil. florins (10 percent) would increase VOC trade by 2.8 mil. florins and lead to 3.7 additional voyages over the next five years. These increases would have been substantial given that drawing balances at the Bank were used to support all types of commercial activity in the city, not just that of the VOC. Panel (c) shows that a 1 percent change in the amount of gold, silver, and coin sent East by the VOC led to return 
cargoes that were about 0.26 percent larger. Evaluated at the sample means, this implies that for every florin in precious metals sent out, incoming cargoes over the next five years were worth 3.7 florins more. The VOC seems to have deployed its metallic resources efficiently in the East Indies. In panel (d), a one percent change in BA balances is associated with a 3.4 percent increase in VOC money exports over a 5-year period.

In the lower panels of Table 1, I switch to a specification in real levels (i.e., without taking $\operatorname{logs}$ ) to allow the outstanding debt of the VOC at the Bank of Amsterdam, which contains zero values in several years, to enter the systems in place of money exports. I did this as an initial test of whether the VOC faced financing constraints in its operations. Interestingly, VOC debt does not Granger-cause VOC investment in either systems, though it does respond negatively to increased trade and shipping activity. This might mean that when the Company needed to get voyages underway, the Bank did not stand in the way of providing working capital, and that once equipped, the VOC's demand for debt fell off. This is not the type of behavior that one would expect from a company that was having trouble raising cash in the local financial market.

\subsection{Finance and the $Q$-Theory of Investment}

The Q-theory of investment as first described by Brainard and Tobin (1968) says that a firm's investment rate should rise with its Q (the ratio of market value to the replacement cost of capital). Fazarri, Hubbard and Peterson's (1988, FHP) study of financing behavior among U.S. firms in the 1980's, however, casts doubt on a single-factor Q-theory in favor of one in which access to the capital market figures prominently. Indeed, FHP's firm-level regressions show that cash flow explains investment more effectively than a host of alternatives and that $\mathrm{Q}$ is not a significant determinant of investment when cash is included in the model. This effect probably occurs because small firms have more limited access to external capital, which makes financing constraints bind more sharply when borrowing channels dry up. Since the VOC was a large company, one would not 
Table 2

VAR models of Q and investment, Dutch East India Company 1723-1794

\begin{tabular}{|c|c|c|c|c|c|c|c|c|c|}
\hline Eq. & $\begin{array}{l}\text { Mkt. value } \\
\text { VOC trade }\end{array}$ & $\begin{array}{c}\text { BA drawing } \\
\text { balances }\end{array}$ & VOC Q & Adj. $\mathrm{R}^{2}$ & Eq. & $\begin{array}{c}\# \text { VOC } \\
\text { voyages }\end{array}$ & $\begin{array}{c}\text { BAdrawing } \\
\text { balances }\end{array}$ & VOC Q & Adj. $R^{2}$ \\
\hline 1a & $\begin{array}{c}0.399 \\
(0.001)\end{array}$ & $\begin{array}{l}-0.211 \\
(0.178)\end{array}$ & $\begin{array}{c}0.062 \\
(0.004)\end{array}$ & 0.467 & $1 \mathrm{a}$ & $\begin{array}{c}0.111 \\
(0.786)\end{array}$ & $\begin{array}{c}-0.103 \\
(0.812)\end{array}$ & $\begin{array}{c}0.050 \\
(0.098)\end{array}$ & 0.032 \\
\hline $1 b$ & $\begin{array}{l}-0.088 \\
(0.826)\end{array}$ & $\begin{array}{c}0.413 \\
(0.000)\end{array}$ & $\begin{array}{c}0.029 \\
(0.438)\end{array}$ & 0.296 & $1 b$ & $\begin{array}{c}0.054 \\
(0.642)\end{array}$ & $\begin{array}{c}0.477 \\
(0.000)\end{array}$ & $\begin{array}{c}0.015 \\
(0.549)\end{array}$ & 0.323 \\
\hline $1 \mathrm{c}$ & $\begin{array}{l}-0.004 \\
(0.590)\end{array}$ & $\begin{array}{l}-0.285 \\
(0.661)\end{array}$ & $\begin{array}{c}0.972 \\
(0.000)\end{array}$ & 0.892 & $1 \mathrm{c}$ & $\begin{array}{c}0.114 \\
(0.638)\end{array}$ & $\begin{array}{l}-0.080 \\
(0.583)\end{array}$ & $\begin{array}{c}0.964 \\
(0.000)\end{array}$ & 0.897 \\
\hline Eq. & $\begin{array}{l}\text { Mkt. value } \\
\text { VOC trade }\end{array}$ & $\begin{array}{c}\text { VOC debt } \\
\text { at BA }\end{array}$ & VOC Q & Adj. $R^{2}$ & Eq. & $\begin{array}{c}\text { \# VOC } \\
\text { voyages }\end{array}$ & $\begin{array}{c}\text { VOC debt } \\
\text { at BA }\end{array}$ & VOC Q & Adj. $R^{2}$ \\
\hline 1a & $\begin{array}{c}0.303 \\
(0.013)\end{array}$ & $\begin{array}{l}-0.399 \\
(0.126)\end{array}$ & $\begin{array}{c}0.748 \\
(0.000)\end{array}$ & 0.550 & $1 \mathrm{a}$ & $\begin{array}{c}0.060 \\
(0.942)\end{array}$ & $\begin{array}{c}0.343 \\
(0.532)\end{array}$ & $\begin{array}{c}1.680 \\
(0.055)\end{array}$ & 0.055 \\
\hline $1 b$ & $\begin{array}{l}-0.103 \\
(0.135)\end{array}$ & $\begin{array}{c}0.782 \\
(0.000)\end{array}$ & $\begin{array}{c}0.097 \\
(0.760)\end{array}$ & 0.827 & $1 b$ & $\begin{array}{c}0.015 \\
(0.027)\end{array}$ & $\begin{array}{c}0.866 \\
(0.000)\end{array}$ & $\begin{array}{l}-0.045 \\
(0.884)\end{array}$ & 0.829 \\
\hline $1 \mathrm{c}$ & $\begin{array}{l}-0.021 \\
(0.517)\end{array}$ & $\begin{array}{c}-0.032 \\
(0.709)\end{array}$ & $\begin{array}{c}0.973 \\
(0.000)\end{array}$ & 0.891 & $1 \mathrm{c}$ & $\begin{array}{c}0.009 \\
(0.335)\end{array}$ & $\begin{array}{l}-0.021 \\
(0.335)\end{array}$ & $\begin{array}{c}0.938 \\
(0.000) \\
\end{array}$ & 0.899 \\
\hline
\end{tabular}

See note for Table 1. 
expect it to face financing constraints in today's relatively efficient U.S. capital market, but it certainly might face them in a less developed market due to the business-cycle effects on the availability of loanable funds

The VARs reported in Table 2 examine whether such constraints were active between 1723 and 1794, which is the period when continuous annual prices of VOC shares are available (see fn. 2). Like their counterparts in Table 1, these systems include either the market value of VOC trade or the number of outgoing voyages as measures of investment, but now also include the VOC's Q at the end of each year. ${ }^{7}$ By then adding either drawing account balances or VOC debt at the BA, I can examine whether Q is indeed the only determinant of investment as the theory would suggest, or whether, as in FHP, the other financing variables obliterate Q. The results in Table 2 are striking in that Q matters for explaining VOC investment (equation 1a) in all four VARs, while neither drawing balances nor VOC debt are significant determinants. Taken alongside Table 1, this suggests that VOC investment did not only grow with the capital market, but that temporary fluctuations in credit conditions within the Bank of Amsterdam did not alter capital budgeting decisions being made by the Company Directors. Rather, the Amsterdam capital market was deep enough for the VOC to secure the funds needed for investment based on its shadow price and did not rely on the official bank of exchange. This seems to reflect financial development in a most fundamental sense.

\section{ENGLAND}

\subsection{Finance, Trade, and the Industrial Revolution}

England's "financial revolution" can be traced to Dutch innovation that accompanied William III as he crossed the North Sea to accept the British throne in 1688, but the event really

\footnotetext{
${ }^{7}$ The VOC did not change its share capital over the 71-year period that I consider so that the Q of VOC equity is the ratio of price to par value of the shares.
} 
involved two phases - the first being pre-Industrial and the second Industrial. It is fortunate that the financial institutions that arose to facilitate both internal and external trade and to stabilize the monetary system in the half-century after the Glorious Revolution left the nation poised to overcome the political and social obstacles of financing an Industrial Revolution.

British finance got a strong start with the founding of the Bank of England (BE) in 1694.

Over its first fifty years, the BE would become, to quote R. D. Richards (1934, p. 272), "a credit institution, an organ of State Finance, a discount and issuing house, a bullion warehouse, and a safe repository." Shortly after its founding, the Bank re-coined the nation's metallic currency and engaged in various note-issuing experiments, both of which promoted monetization of the economy and brought some order to a disheveled monetary system. And while the Bank's integral relationship with the State has received the most attention among its scholars, the Bank's support of London's merchant and trading communities through its clearing and discounting facilities was too large to be overlooked (see Clapham, 1941). Indeed, it is the monetization and the private business roles of the Bank that I will focus upon in this section.

Before 1750, the Bank of England co-existed only with a group of private bankers in London who dealt primarily in deposits and bills of exchange. This gave rise to an active money market to finance trade and working capital for the fledgling manufacturing sector, and the BE played a key role in its smooth operation. A stock exchange emerged by the 1690 's to facilitate transactions in public debt securities and shares of the large trading companies, including the British East and West India Companies, the South Sea Company, and the Royal African Company. In short, England quickly achieved what Richard Sylla and I have listed as four of the five elements of a "good" financial system: (i) sound public finance, (ii) stable money, (iii) a central bank, and (iv) wellfunctioning securities markets (Rousseau and Sylla, 2001, pp. 2-3). 
With a reasonably "good" system in place by 1750 , it remained for the financial sector to develop the final feature: $(v)$ a variety of banks. Indeed, country banks did not spring up until the second half of the 18th century, but made up for lost time by multiplying rapidly, issuing their own notes to facilitate transactions outside of London, and fostering correspondent relationships with London's private bankers. ${ }^{8}$ Savings banks started up after 1817 to provide a vehicle for the surpluses of less-wealthy individuals, but were never large enough to be a very important part of the financial landscape. Major legislation enacted in 1826 ended the BE's long-standing monopoly in the jointstock banking business, and though institutions (perhaps surprisingly) did not form immediately in response, by 1840 there were more than 600 joint-stock banks.

Amidst such important financial advances, England was also undergoing a commercial and industrial revolution. Figure 3 shows that the real value of international trade, defined as the sum of imports, domestic exports, and re-exports, rose by 50 percent between 1720 and 1760, and another 50 percent between 1760 and $1805 .{ }^{9}$ When viewed alongside earlier data for the English East India Company that indicates a more than six-fold increase in Asian exports between 1660 and 1710, the rapid commercialization of the British economy comes into clear focus. Hoffman's index of industrial production (Mitchell, 1988, Table 8.21.A, pp. 431-432, including building), also shown in Figure 3, progresses less rapidly than the trade series at first, but accelerates after 1780, and once

\footnotetext{
${ }^{8}$ Relatively little is known about the extent of country banking in 18th century England and its contribution to the money supply. These banks were generally small, but grew rapidly in number. Cameron (1967, pp. 23-24) reports that "about a dozen" existed in 1750, more than 100 in the early 1780 's, more than 300 by 1800 , and 783 in 1810 .

${ }^{9}$ The trade data are from Mitchell (1988), Table 10.1.A, pp. 448-449 for England and Wales 1720-1791, Table 10.1.B, p. 450 for Great Britain 1792-1804, and Table 10.2, pp. 451-452 for the U.K. 1805-1850. I start with the earlier and more narrow trade figures for England and Wales and then successively join the broader aggregates to form a single trade series. I form the price deflator using Mitchell (1988) by joining the Schumpeter-Gilboy index for consumer goods for 1720-1819 (Table 14.1.B, pp. 719-720) with Rousseaux's overall index for 1820-1845 (Table 14.3, p. 722) and the Sauerbeck-Statist index for 1847-1850 (Table 14.4, p. 725).
} 


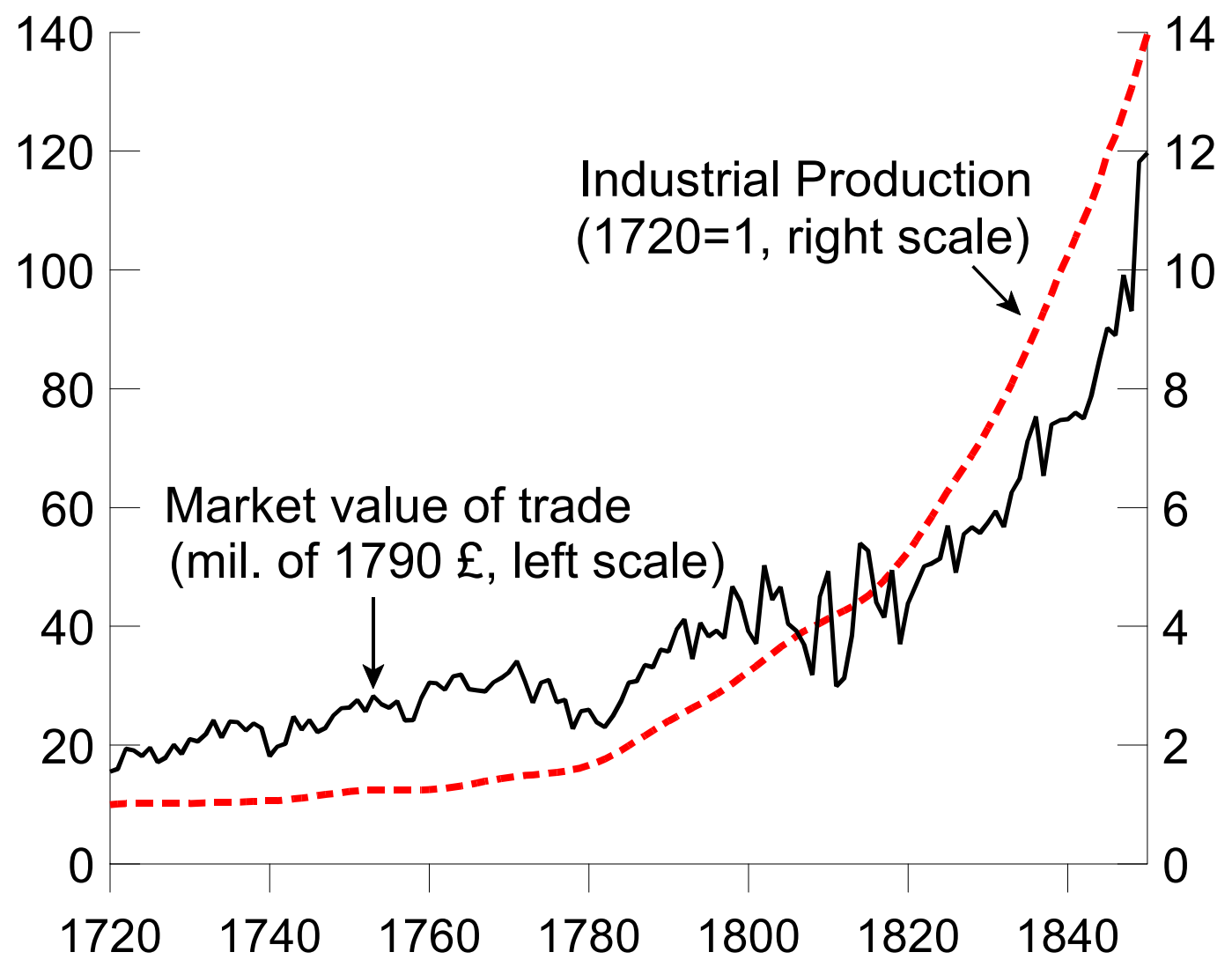

Figure 3. Real Industrial Production and International Trade, England 1720-1850.

again around 1818, and thus seems to share the rhythm of the later part of the trade boom. The available macro economic time series, in other words, are consistent with the initial development of a commercial sector that later nurtured and was complemented by a growing manufacturing sector by the end of the 18 th century.

\subsection{Finance as a Leading Sector}

Did England's financial system promote the co-evolution of trade and industry? To address this question quantitatively and in a macro economic sense, it is necessary to construct a measure of monetization. This is easier for the period before 1775 because London's private bankers had stopped issuing notes, which had always been a small part of their business, years earlier due to 
competition from the BE (Cameron, 1967, p. 22). It is thus fair to say that coin and BE notes made up the circulating medium used in London before 1750 and a large part of what circulated outside of the city as well. This is useful because time series for the circulation and deposit liabilities of the BE are available almost from its inception. The rise of deposit banking in the countryside after 1775 and a lack of reliable information about net specie imports, however, doom any attempt to build a continuous series for an M2 aggregate. Nevertheless, Figure 4 shows a strong long-term relationship between the BE's deposit and circulation liabilities and Cameron's (1967, p. 42) sporadic estimates of the broad money supply. ${ }^{10}$ Further, Huffman and Lothian's (1980) estimates of high-powered money for the $1833-1850$ period (not shown) track BE liabilities closely from 1840 to 1850 , which is the period when the issues of the joint-stock banks make the trend of the BE series first begin to diverge from the pattern in Cameron's estimates. These observations offer reason to believe that the BE's deposit and circulation liabilities are a usable proxy for long-term fluctuations in narrowlydefined money, and perhaps even as a more general measure of monetization.

Part of the Bank's business was in making advances to merchants with drawing accounts, though not all those with accounts were entitled to discount (Clapham, 1941). The Bank also made over ninety loans to the East India Company between 1709 and 1744, but these direct loans, though exceeding bill and note discounts in the Bank's early days, did not become an important component of the asset portfolio until the 1750's (see Figure 4). The Bank's private operations grew rapidly after that, and even approached the size of its deposit and circulation liabilities during the 1760's and

${ }^{10}$ The circulation and deposit liabilities of the Bank of England are from Mitchell (1988, Table 12.2.A, pp. 655-658). I reconstructed a series for the Bank's private advances as the income from discounting bills and notes and making private loans (Clapham, 1945, Vol. I, Appendix E, pp. 301302, and Vol. II, Appendix C, p. 433) divided by the Bank rate over the previous year (Clapham, 1945, Vol. I, Appendix D, p. 299, discount rates for inland bills, and Vol. II, Appendix B, pp. 429. This assumes that the BE's loans were primarily short term, which is consistent with Clapham's reading of the loan records. 


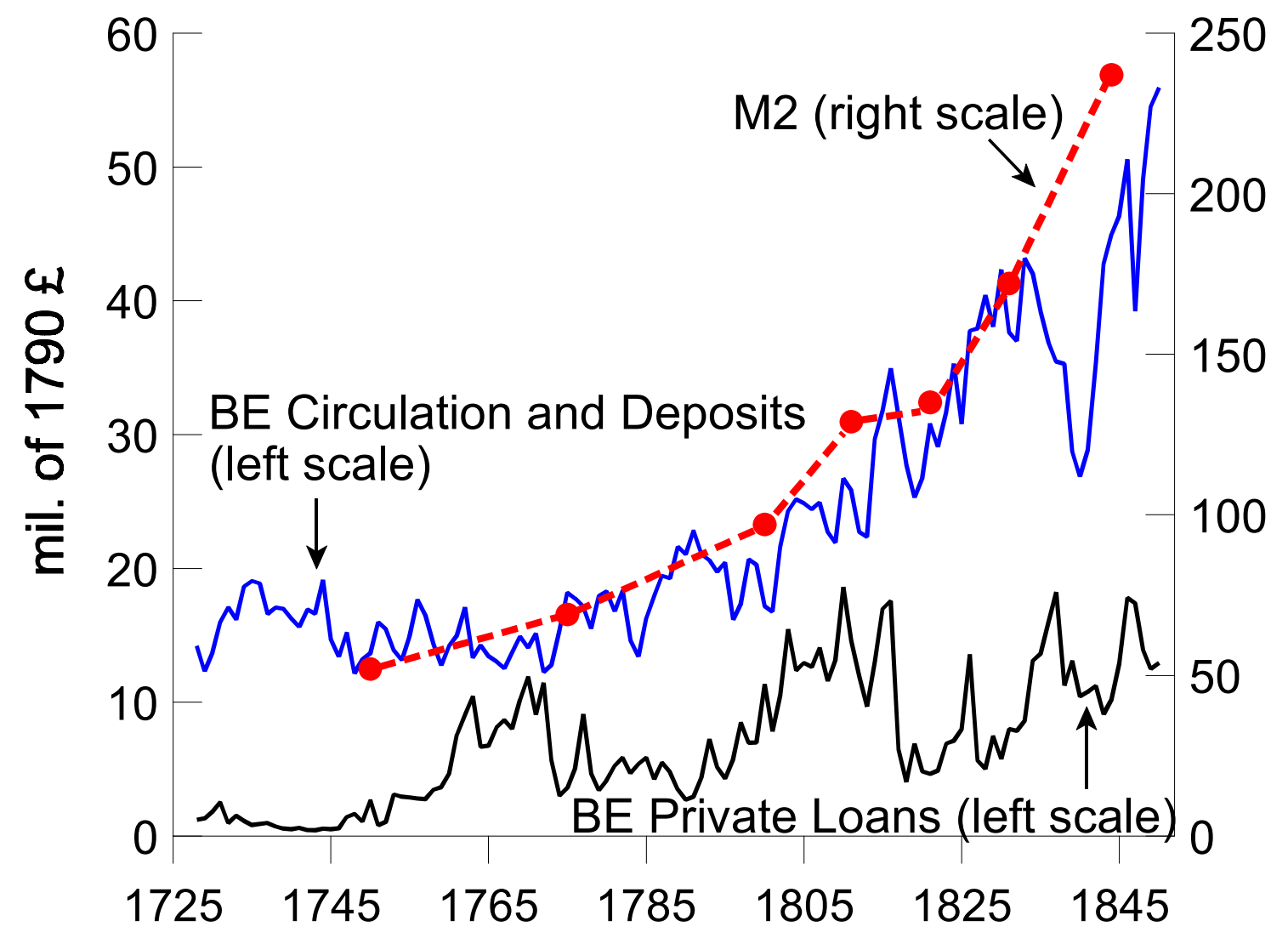

Figure 4. Monetary Aggregates, England 1728-1850.

again around 1800. Evidence from the Bank archives show that loans and discounts were spread across a wide range of commercial activities, and that discounts below the statutory limit of $£ 50$ were not unusual. Since advances were also used to facilitate trade, fluctuations in their availability may have also affected the course of trade. This is among the possibilities that I examine below.

\subsection{Quantitative Results with the Aggregate Data}

The empirical analysis proceeds as in Section 1, but the two VARs that I consider first capture economic activity in a more general sense than was possible for the United Provinces. The first system explores dynamic interactions between industrial production, trade, and monetization as measured by the BE's deposit and circulation liabilities. In the second, I replace the measure of 
Table 3

VARs of financial and real activity, England 1728-1850

\begin{tabular}{|c|c|c|c|c|}
\hline Eq. & $\begin{array}{c}\text { Industrial } \\
\text { production index }\end{array}$ & $\begin{array}{c}\text { Market value } \\
\text { trade } \\
\end{array}$ & $\begin{array}{c}\text { Bank of England } \\
\text { liabilities } \\
\end{array}$ & $\begin{array}{c}\text { Adjusted } \\
\mathrm{R}^{2} \\
\end{array}$ \\
\hline $1 \mathrm{a}$ & $\begin{array}{c}1.011 \\
(0.000)\end{array}$ & $\begin{array}{l}-0.006 \\
(0.282)\end{array}$ & $\begin{array}{c}0.013 \\
(0.088)\end{array}$ & 0.991 \\
\hline $1 b$ & $\begin{array}{c}0.162 \\
(0.046)\end{array}$ & $\begin{array}{c}0.798 \\
(0.000)\end{array}$ & $\begin{array}{l}-0.053 \\
(0.390)\end{array}$ & 0.940 \\
\hline $1 \mathrm{c}$ & $\begin{array}{c}0.058 \\
(0.261)\end{array}$ & $\begin{array}{c}0.071 \\
(0.201)\end{array}$ & $\begin{array}{c}0.808 \\
(0.000)\end{array}$ & 0.924 \\
\hline Eq. & $\begin{array}{c}\text { Industrial } \\
\text { production index }\end{array}$ & $\begin{array}{c}\text { Market value } \\
\text { trade } \\
\end{array}$ & $\begin{array}{c}\text { Bank of England } \\
\text { private loans }\end{array}$ & $\begin{array}{c}\text { Adjusted } \\
\mathrm{R}^{2} \\
\end{array}$ \\
\hline $1 \mathrm{a}$ & $\begin{array}{l}1.030 \\
(0.000)\end{array}$ & $\begin{array}{l}-0.025 \\
(0.465)\end{array}$ & $\begin{array}{c}0.001 \\
(0.869)\end{array}$ & 0.990 \\
\hline $1 b$ & $\begin{array}{c}0.197 \\
(0.001)\end{array}$ & $\begin{array}{c}0.645 \\
(0.000)\end{array}$ & $\begin{array}{c}0.030 \\
(0.156)\end{array}$ & 0.941 \\
\hline $1 \mathrm{c}$ & $\begin{array}{l}-0.123 \\
(0.226)\end{array}$ & $\begin{array}{c}0.392 \\
(0.002)\end{array}$ & $\begin{array}{c}0.887 \\
(0.000)\end{array}$ & 0.888 \\
\hline
\end{tabular}

NOTE: See note to Table 1. The VARs use three lags that were selected with nested likelihood ratio tests. Data are in real log levels.

monetization with the quantity of private loans and discounts at the BE, which should reflect the stringency of credit conditions in the London money market.

Table 3 reports the findings. ${ }^{11}$ Given the data limitations of early British data, it is striking that BE liabilities do indeed Granger-cause industrial production at the 10 percent level in the upper panel, and that this effect is unidirectional. If BE liabilities reflect monetization as I have suggested, this means that finance moved before output in England's modern sector, and may well have played

${ }^{11}$ As in the analysis for the Netherlands, the unit root hypothesis cannot be rejected for any of the variables considered in this section using ADF tests with three lags, and Johansen tests indicate that the systems are cointegrated. See the Appendix for details. 
a leading role in its development. Interestingly, monetization did not affect trade quantities, yet increases in domestic industrial production did, and this effect is also unidirectional. A pattern in which finance affects output and output affects trade emerges.

In the lower panel of Table 3, BE lending does not Granger-cause industrial production, but does Granger-cause trade at the 15 percent level. Though this result is not statistically significant at conventional levels, the BE's tendency to make private loans during times of greater stringency in the external money market may weaken what would otherwise have been a tight and direct relationship between BE lending and credit market conditions, especially after the Bank expanded its discounts around 1800. On the other hand, trade does Granger-cause BE lending, and the relationship seems to be positive and bi-directional. Since periods of high demand for trade credit are likely to coincide with surges in real trading activity, a bi-directional relationship might be expected.

Figure 5 displays selected impulse responses. In the upper left panel, a 1 percent increase in "monetization" is associated with persistent increases in industrial production that cumulate to 1.39 percent after five years. In the upper right panel, a 1 percent increase in industrial production increases trade by about 0.95 percent over the same period. The response of trade to a 1 percent rise in BE loans, though not significant in the Granger-tests, is "significantly" positive (i.e., the lower one-standard error band stays above the zero-line) for nine periods and cumulates to a 0.2 percent after five years. As suggested by the Granger tests, the effect of monetization on trade is small.

\subsection{Financing Constraints and the English East India Company}

The British version of the Asiatic trade behemoth, the English East India Company (EIC), formed at about the same time as its Dutch counterpart (1601), but remained a loosely knit group of merchants operating in the shadow of its North Sea rival for decades before creating a permanent capital of $£ 369,891$ in 1657 . The Company’s early operations were limited by an inability to garner 


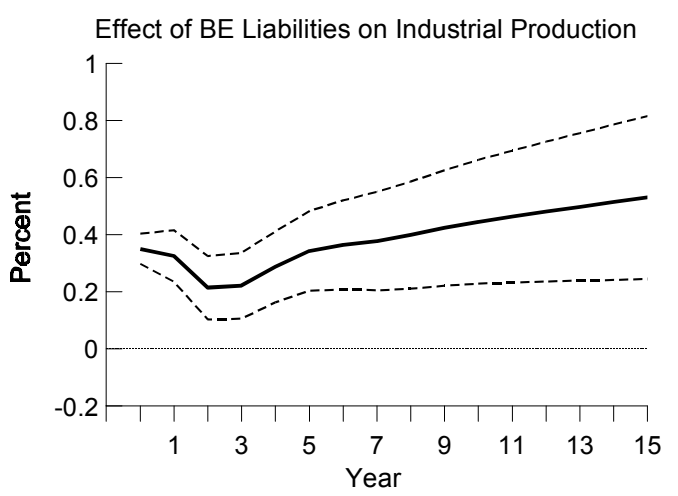

(a)

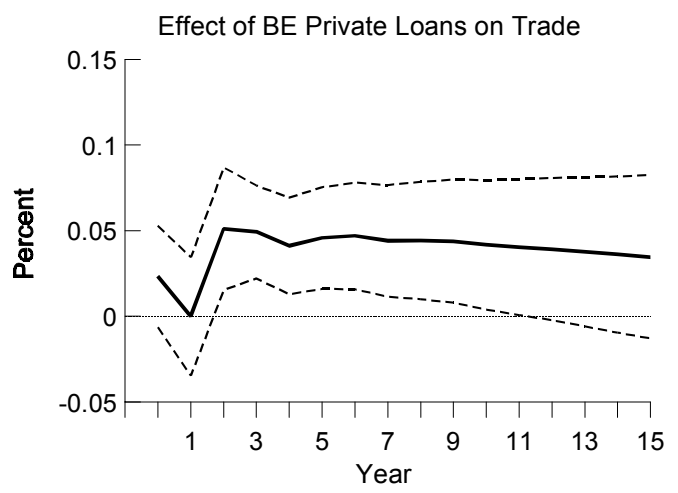

(c)

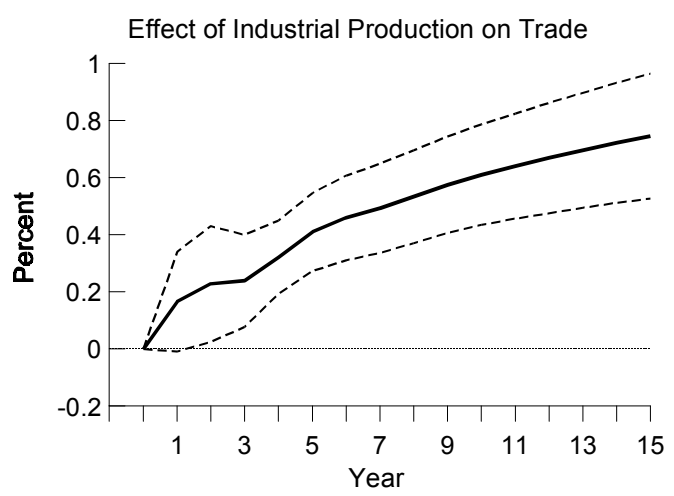

(b)

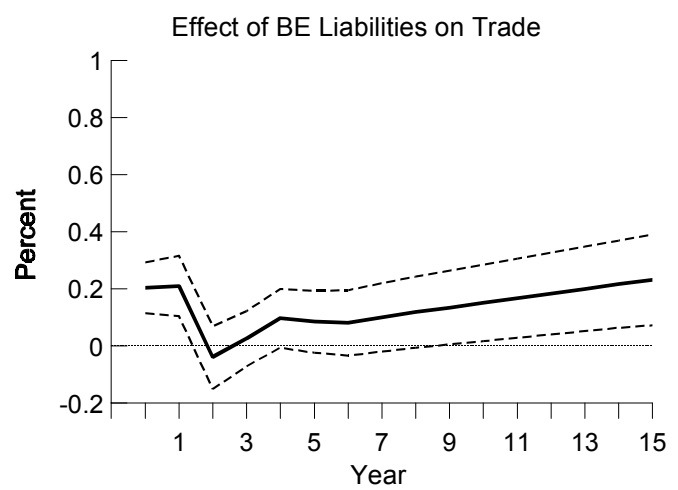

(d)

Figure 5. Selected impulse responses from VAR systems for England, 1728-1850.

Note: The impulse responses are taken from the VAR systems reported in Table 3. The ordering places BE deposit and circulation liabilities or BE private loans first, the real market value of trade second, and real industrial production third. Using Monte Carlo integration, the solid lines are the mean impulse responses that result from 10,000 random draws from the posterior distribution of the estimated VAR coefficients. The dotted lines are one standard error bands.

recently-mined American silver in quantities that the Dutch VOC could command. The presence of more developed financial and trading institutions in Amsterdam to handle specie flows is a likely explanation for the early pre-eminence of the Dutch, but the English company managed to expand operations early in the 18th century following a merger in 1708 with a competing English trading company (Chadhuri, 1978, pp. 7-10).

The EIC's capital was small compared to the turnover of its operations, and as such it 
depended heavily on short-term debt and internally-generated funds to get voyages out to sea. If financing were a problem for the Company in the 17th century, as much anecdotal evidence suggests that it was, yet became a less binding constraint as the English financial system developed, we should observe the availability of cash or debt finance as a less important determinant of the Company's investment activities than something more fundamental such as the quality of investment opportunities, at least for the first half of the 18th century. Because the available data cover the heyday of the EIC, the Q-theory analysis that follows is even more telling for the efficiency of English finance than that presented in the previous section for the VOC, which covered the period of gradual decline for the Dutch enterprise.

By 1710 a number of government securities traded on the London Stock Exchange beside shares of the main trading companies, and Castaing's Course of the Exchange (the Wall Street Journal of its day) carried the share prices. Due to the painstaking work of Larry Neal (1990, pp. 231-257), we now have a nearly complete picture of EIC share price from this point onward. Balance sheet data, including cash balances, debt levels, and trading values are available for 1710-1745 from Chadhuri (1978). ${ }^{12}$ The econometric specifications that I consider are similar to those estimated for the VOC (see Table 2), where Q controls for the quality of the EIC's investment opportunities as perceived by the stock market, exports proxy for actual investment, and the firm's cash balances and total debt alternately enter the model to capture the dependence of the Company's investment on the availability of cash resources.

The results, which are displayed in Table 4, offer strong evidence that financing constraints did not bind for the EIC over this period. In the upper panel, Q Granger-causes investment at the 5 percent level, while the firm's cash balances do not approach statistical significance. The effects are

${ }^{12}$ Asian exports of the EIC are from Chadhuri (1978), Table C.1, p. 507. The EIC's cash balances and total bond debt are from Table A.26, col. 3, p. 440. 
Table 4

VAR models of Q and Trade, British East India Company 1710-1745

\begin{tabular}{|c|c|c|c|c|}
\hline Eq. & $\begin{array}{l}\text { Market value } \\
\text { EIC trade }\end{array}$ & $\begin{array}{c}\text { EIC } \\
\text { total debt }\end{array}$ & EIC Q & $\begin{array}{c}\text { Adjusted } \\
\mathrm{R}^{2} \\
\end{array}$ \\
\hline $1 \mathrm{a}$ & $\begin{array}{c}0.979 \\
(0.090)\end{array}$ & $\begin{array}{l}-0.804 \\
(0.386)\end{array}$ & $\begin{array}{c}0.382 \\
(0.042)\end{array}$ & 0.591 \\
\hline $1 b$ & $\begin{array}{c}0.423 \\
(0.004)\end{array}$ & $\begin{array}{c}0.077 \\
(0.636)\end{array}$ & $\begin{array}{c}-0.089 \\
(0.131)\end{array}$ & 0.770 \\
\hline $1 \mathrm{c}$ & $\begin{array}{l}-0.069 \\
(0.149)\end{array}$ & $\begin{array}{c}0.117 \\
(0.254)\end{array}$ & $\begin{array}{c}0.449 \\
(0.000)\end{array}$ & 0.653 \\
\hline Eq. & $\begin{array}{l}\text { Market value } \\
\text { EIC trade }\end{array}$ & $\begin{array}{c}\text { EIC } \\
\text { cash balance }\end{array}$ & EIC Q & $\begin{array}{c}\text { Adjusted } \\
\mathrm{R}^{2} \\
\end{array}$ \\
\hline $1 \mathrm{a}$ & $\begin{array}{c}0.344 \\
(0.388)\end{array}$ & $\begin{array}{l}-0.241 \\
(0.783)\end{array}$ & $\begin{array}{c}0.399 \\
(0.073)\end{array}$ & 0.550 \\
\hline $1 b$ & $\begin{array}{l}-0.590 \\
(0.198)\end{array}$ & $\begin{array}{l}-0.335 \\
(0.441)\end{array}$ & $\begin{array}{c}0.057 \\
(0.965)\end{array}$ & 0.012 \\
\hline $1 \mathrm{c}$ & $\begin{array}{c}-0.513 \\
(0.151)\end{array}$ & $\begin{array}{c}-0.491 \\
(0.191)\end{array}$ & $\begin{array}{c}0.567 \\
(0.000)\end{array}$ & 0.891 \\
\hline
\end{tabular}

See note for Table 1. The VARs use three lags. EIC trade and debt are in real log levels in the upper panel. Due to negative observations for cash, EIC trade and cash balances enter the VAR in the lower panel as real levels.

also unidirectional in a statistical sense, as evidenced by a lack of Granger-causality from either exports or cash balances to Q (see the third line of the upper panel). The results are similar in the lower panel when the EIC's external debt replaces cash balances as the financial variable. These results suggest that the EIC may have been constrained by the quality of its investment opportunities, but that the availability of finance did not enter into investment decisions. This is, as in the Dutch case, characteristic of a capital market that can mobilize the resources needed for economic development. And though the VAR systems are silent on whether such unconstrained access to capital was available for smaller merchants and manufacturers, "good" institutional arrangements seem to have been in place for firms that had achieved some degree of public reputation. 


\section{THE UNITED STATES}

\subsection{A "Federalist Financial Revolution?"}

Any skeptic of the importance of finance in promoting economic development must come to grips with the powerful case of the United States after adoption of the Federal Constitution in 1788. At no other point in history did the five elements of a "good" financial system develop so rapidly. Much of the credit for what Richard Sylla (1998) has termed the "Federalist financial revolution" seems appropriate to bestow upon the nation's first Secretary of the Treasury, Alexander Hamilton, though the impact of Hamilton's reforms on the real side of the economy were perhaps not fully felt for another quarter century, when the "modern" sector finally emerged.

By any standards, the U.S. economy experienced a near-miraculous turnaround in the last decade of the 18th century, when it made the transition from a defaulting debtor awash in obligations left over from the war of independence to a magnet for international capital flows. The chartering of a national bank, the First Bank of the United States, and Hamilton's ingenious idea of allowing Federal debt securities to be tendered for shares therein, quickly raised the re-structured U.S. debt, which had been trading at pennies on the dollar through informal channels, to par and above by 1791. Securities markets in New York, Philadelphia and Boston quickly sprung up to trading these securities and others associated directly with internal improvements.

Hamilton also established a federal mint, bringing order to the collection of foreign coins and various issues of fiat paper that had previously comprised the nation's money stock under a bimetallic standard. Over the next fifty years, the number of banks would rise from 3 in 1791 to more than 800 , and the paid-in capital of the banking system would increase by more than 100 -fold!

Given the speed with which a sophisticated financial sector emerged in the U.S., it is surprising that economic historians have only recently begun to consider seriously its implications 


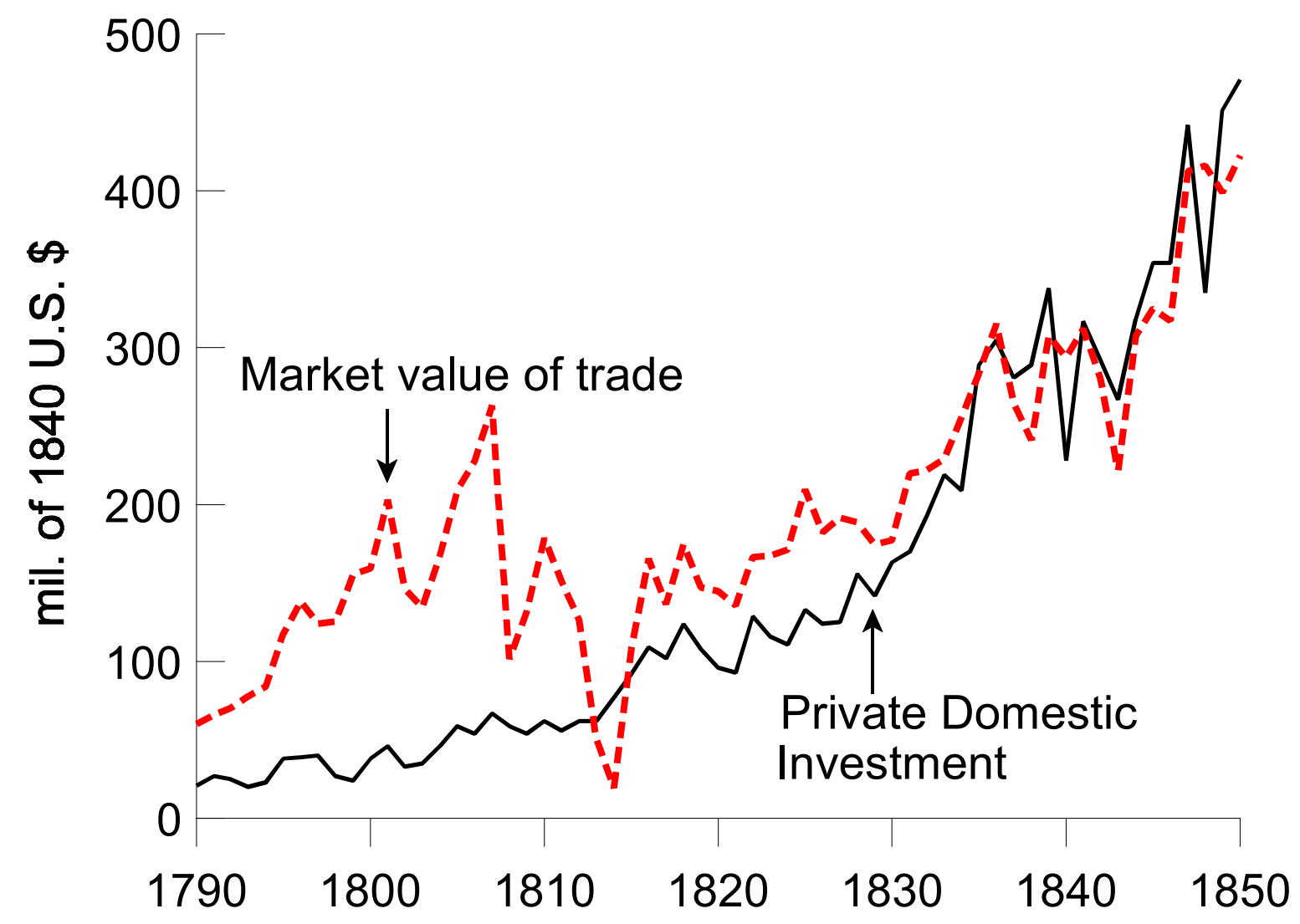

Figure 6. Investment and Foreign Trade in the United States 1790-1850.

for the nation's early growth. This is probably because agriculture remained dominant for most of the 19th century, making measures of early gross national product, such as those of David (1967) or Berry (1988), not reflect growth in the "modern" sector very well - that is, the part of the economy that would have relied most on the types of financing arrangements that were available in the U.S. markets of the time.

\subsection{Measures of Financial and Real Sector Development}

As in the analyses of the Dutch Republic and England above, it is the development of the this "modern" sector, as measured by foreign trade and investment activity, that I will focus upon in 
the empirical analysis. ${ }^{13}$ Figure 6 presents the series. Both trade and investment rise slowly in real terms until 1815 when they begin to accelerate, which is consistent with the rise of a modern sector at about this time.

On the financial side, a measure of monetization is again needed. And though it is difficult to measure the quantity of specie in the hands of the public - the most important component of the money stock in the early national period - with any degree of confidence, Rousseau and Sylla (1999) use the available data to extend Peter Temin's (1969) series, which begins in 1820, back to 1790 by replicating Temin's method as closely as possible. ${ }^{14}$ The resulting series includes obligations of banks to the public and specie outside of banks, and thus represent assets that are either acceptable or quickly convertible for use in market transactions. Increases in the real value of these assets reflect more widespread use of the market economy, and might be plausibly linked to trade and investment.

It is also for the United States that I can first introduce securities markets explicitly into the empirics. Rousseau and Sylla (1999, pp. 7-12) collected the total number of securities listed in the financial press for three major cities (New York, Philadelphia and Boston) around the end of each calendar year from 1790 to 1850 , and I will use this as a robust measure of the size (and perhaps the sophistication) of the securities market.

Figure 7 displays financial series. Both money and securities listings grow slowly until about 1815 when they begin to rise quickly. Overall, both series grow at an average rate of about 4.5 percent per year, which is higher than the 1.9 percent growth rate of GDP (Berry 1988) and implies rapid financial deepening.

\footnotetext{
${ }^{13}$ Foreign trade is the sum of total exports and imports (Historical Statistics of the United States, series U1 and U8, pp. 865-866). Gross domestic investment is from Berry (1988).

${ }^{14}$ The data and methods used to construct the annual series for the U.S. money stock are described in detail in Appendix A of Rousseau and Sylla (1999, pp. 48-50), and the series will appear in the forthcoming millennial edition of the Historical Statistics of the United States.
} 


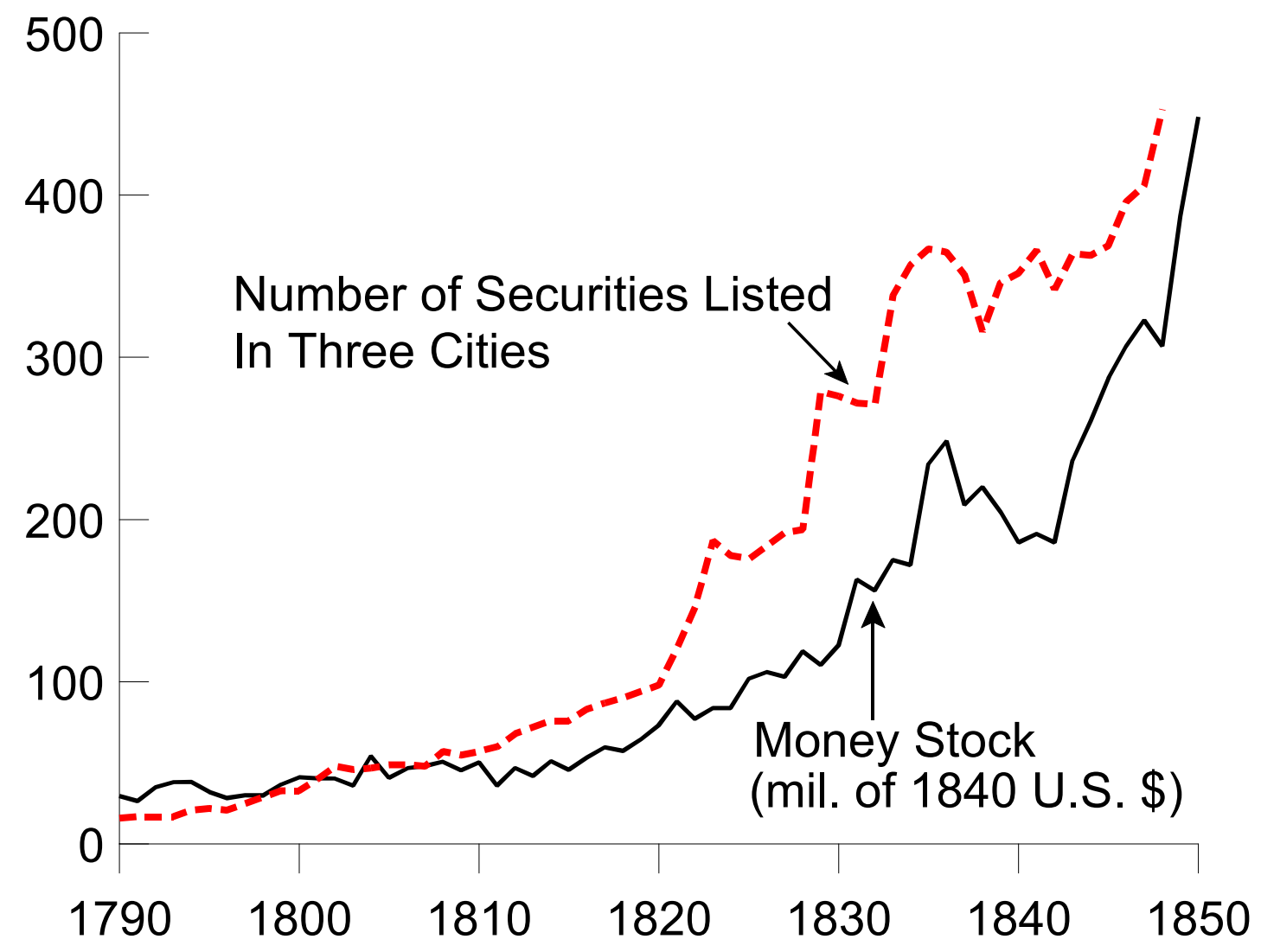

Figure 7. Monetary and Financial Aggregates, United States 1790-1850.

\subsection{Time Series Findings}

To explore possible links between the financial and real variables described above, I start with a VAR specification that includes measures of investment, trade, and monetization. I will then add the number of listed securities to this system to measure their additional impact. The method of bringing securities markets into the analysis incrementally is consistent with Levine and Zervos (1998) and Rousseau and Wachtel (2000), who keep a measure of liquid liabilities in their baseline model to allow for complementarities between banks and stock markets in the growth process. All data are transformed into logs before analysis. Table A.1 in the Appendix shows that the four series that I use are statistically indistinguishable from unit root processes, and Table A.2 shows that the two systems are cointegrated, which justifies running the VARs in levels form. 
Table 5

VARs of financial and real activity, United States 1790-1850

\begin{tabular}{|c|c|c|c|c|c|}
\hline Eq. & Investment & $\begin{array}{c}\text { Market value } \\
\text { trade }\end{array}$ & Money stock & $\begin{array}{l}\text { No. listed } \\
\text { securities } \\
\end{array}$ & $\begin{array}{c}\text { Adjusted } \\
\mathrm{R}^{2} \\
\end{array}$ \\
\hline $1 \mathrm{a}$ & $\begin{array}{c}0.717 \\
(0.000)\end{array}$ & $\begin{array}{l}-0.266 \\
(0.094)\end{array}$ & $\begin{array}{c}0.423 \\
(0.018)\end{array}$ & & 0.964 \\
\hline $1 b$ & $\begin{array}{c}-0.239 \\
(0.799)\end{array}$ & $\begin{array}{c}0.377 \\
(0.001)\end{array}$ & $\begin{array}{c}0.549 \\
(0.010)\end{array}$ & & 0.663 \\
\hline $1 \mathrm{c}$ & $\begin{array}{c}0.154 \\
(0.075)\end{array}$ & $\begin{array}{c}0.037 \\
(0.958)\end{array}$ & $\begin{array}{c}0.840 \\
(0.000)\end{array}$ & & 0.973 \\
\hline Eq. & Investment & $\begin{array}{c}\text { Market value } \\
\text { trade }\end{array}$ & Money stock & $\begin{array}{l}\text { No. listed } \\
\text { securities } \\
\end{array}$ & $\begin{array}{c}\text { Adjusted } \\
\mathrm{R}^{2} \\
\end{array}$ \\
\hline $1 \mathrm{a}$ & $\begin{array}{c}0.245 \\
(0.570)\end{array}$ & $\begin{array}{l}-0.253 \\
(0.025)\end{array}$ & $\begin{array}{c}0.281 \\
(0.009)\end{array}$ & $\begin{array}{c}0.470 \\
(0.005)\end{array}$ & 0.972 \\
\hline $1 b$ & $\begin{array}{l}-0.050 \\
(0.918)\end{array}$ & $\begin{array}{c}0.373 \\
(0.001)\end{array}$ & $\begin{array}{c}0.597 \\
(0.004)\end{array}$ & $\begin{array}{l}-0.185 \\
(0.391)\end{array}$ & 0.664 \\
\hline $1 \mathrm{c}$ & $\begin{array}{c}0.089 \\
(0.168)\end{array}$ & $\begin{array}{c}0.032 \\
(0.961)\end{array}$ & $\begin{array}{c}0.823 \\
(0.000)\end{array}$ & $\begin{array}{c}0.074 \\
(0.669)\end{array}$ & 0.971 \\
\hline $1 d$ & $\begin{array}{l}-0.053 \\
(0.772)\end{array}$ & $\begin{array}{l}-0.013 \\
(0.879)\end{array}$ & $\begin{array}{l}-0.015 \\
(0.662)\end{array}$ & $\begin{array}{c}1.042 \\
(0.000)\end{array}$ & 0.991 \\
\hline
\end{tabular}

NOTE: See note to Table 1. The VARs use four lags that were selected with nested likelihood ratio tests. Data are in real log levels. The lower panel reports results from a four-dimensional system, which requires an extra equation (1d) in the VAR.

Table 5 presents the results. In the upper panel, the findings for the three-variable system show that the money stock Granger-causes both real investment (top line, third column) at the 2 percent level, and the value of real trade (second line, second column) at the 1 percent level. Trade Granger-causes investment at the 10 percent level, but has a negative overall effect, which suggests that increases in the import component of trade may have to some degree crowded out investment out in the early U.S. In the lower panel, the results for the four-variable system are similar to the three-variable results insofar as the monetary effects are concerned, yet the size of the securities 


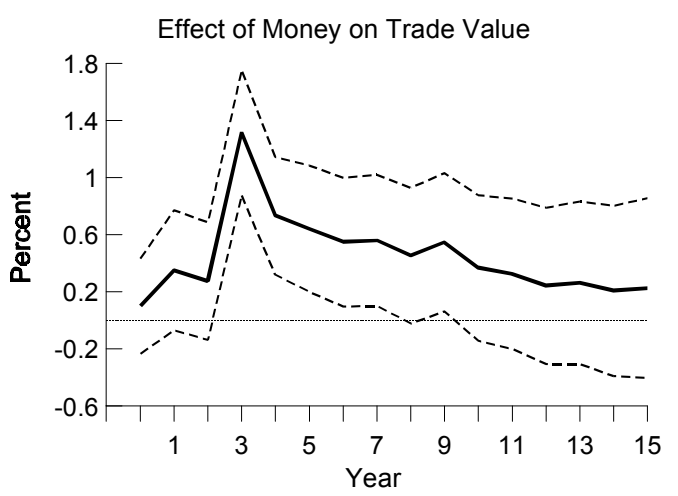

(a)

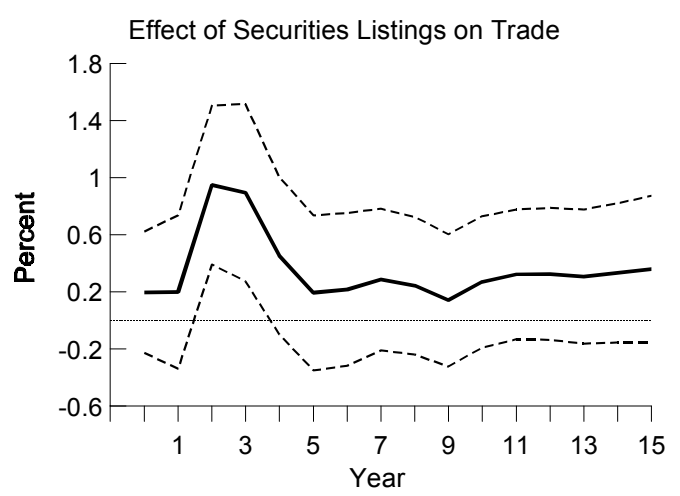

(c)

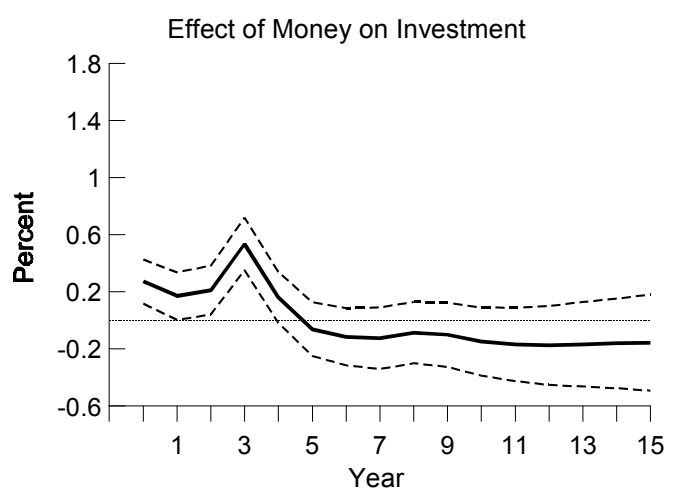

(b)

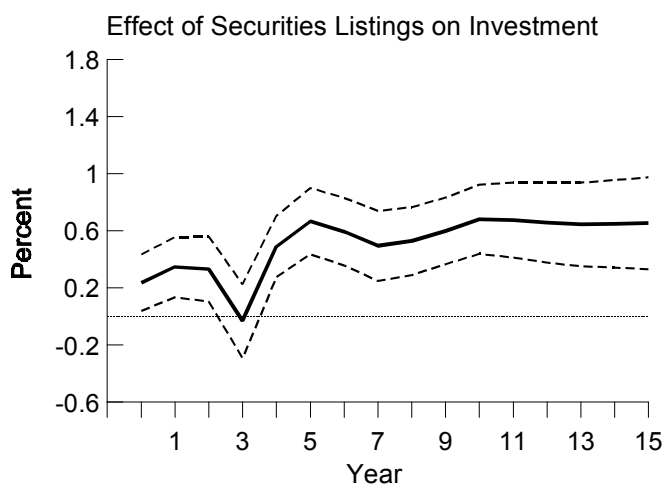

(d)

Figure 8. Selected impulse responses from 4-variable VAR system for the United States, 1790-1850.

Note: The impulse responses are taken from the VAR systems reported in the lower panel of Table 5. The variable ordering places the number of listed securities first, the real money stock second, the real market value of trade third, and real investment last. Using Monte Carlo integration, the solid lines plot the mean impulse responses that result from 10,000 random draws from the posterior distribution of the estimated VAR coefficients. The dotted lines are one standard error bands.

market also exerted a positive and independent effect on investment. Listed securities do not Granger-cause trade, however, which suggests that the rise of securities markets had their largest effects in the domestic capital market.

Figure 8 presents selected impulse responses from the four-variable system in Table 5. In panels (a) and (b), respectively, 1 percent increases in the real stock of money are associated with increases in trade of 2.78 percent and in investment of 1.35 percent after five years. Panels (c) and 
(d) indicate that 1 percent increases in the number of listed securities increase trade by 2.70 percent and investment by 1.37 percent after five years. The result for the effect of listed securities on trade is striking because the Granger tests did not show a significant effect, which is an important reason to consider the non-linear and interactive impulse responses when evaluating VAR systems. The effects of both the money stock and the number of listed securities on trade and investment are of about the same order of magnitude once they have had an opportunity to work their way through the VAR for five years. Thus, even though the financial variables yield different response patterns over time, they are equally as important in fostering commerce and capital accumulation.

There is no doubt that the data that are available for the United States in the early national period are sketchy, yet they have been generated using the best practices available to the economic historian. And the relative strength of the results with these data reveal that the nascent "finance-led growth" hypothesis for the United States at the very least requires much more investigation among macro economists and economic historians alike.

\section{JAPAN}

\subsection{Financial Developments in the Meiji Period}

In the decade that followed the restoration of the Meiji regime in 1868, Japan made a quantum leap in the development of financial markets and foreign trade, and quickened the pace of its industrialization. Scholars of the period such as Ott (1960) and Lockwood (1968) have remarked that the financial sector was instrumental in promoting the adoption of new agricultural and machine-based industrial technologies that allowed Japan to achieve modern rates of economic growth after 1885. This section reviews the empirical evidence for this proposition using available historical statistics and drawing from the more extended analysis in Rousseau (1999).

Among the financial innovations of the 1870 's, the most important was the commutation of rice payments (i.e., taxes) that were normally made to the feudal nobility through an issue of long- 
term government bonds which were redeemable only at heavy discounts. In an action reminiscent of Alexander Hamilton, an 1876 revision of the National Bank Act then allowed these bonds to be used as banking capital. Like its U.S. predecessor, stock markets emerged in Tokyo and Osaka shortly thereafter for trading the fresh securities. A rapid expansion in the number of national banks from 5 in 1876 to 151 in 1879 also ensued (Bank of Japan, 1966, p. 196). Among the new banks was the Yokahoma Specie Bank, which started up in 1880 to meet the foreign exchange needs of merchants who were active in the nation's growing foreign trade. As the economy opened more and more to the West, it was able to import industrial technologies such as the power loom that had been available in Europe and the United States for decades, and was able to do so at relatively low cost.

Japan's financial development was briefly short-circuited in 1880 when note issues of the newly-formed banks flooded the market and caused an episode of sharp inflation, but this experience led to a consolidation of note issuance under the nation's first central bank, which formed in 1882. In short, by 1885 Japan had achieved all five elements of a "good" financial system, and did so almost as quickly as the United States had 80 years earlier.

\subsection{Evidence of Finance-Led Growth in Meiji Japan}

The statistical analysis uses a broad measure of financial development that encompasses the total assets of Japan's most important intermediaries and the book values of corporate debt and equity in the hands of the public. The intermediaries include commercial banks (national, private and ordinary), special banks, savings banks, agricultural cooperatives and insurance companies, but do not include quasi-banks, small credit cooperatives, and country pawnbrokers who according to Goldsmith (1983, p. 27) accounted for as much as 18 percent of all intermediary assets. ${ }^{15}$

${ }^{15}$ The source data used to build the financial and real aggregates are from the Bank of Japan (1966), Ott (1960), and a five-volume series edited by Ohkawa et al. titled Estimates of the LongTerm Economic Statistics of Japan Since 1868. See Rousseau (1999, pp. 196-197) for details on data sources and methods. 


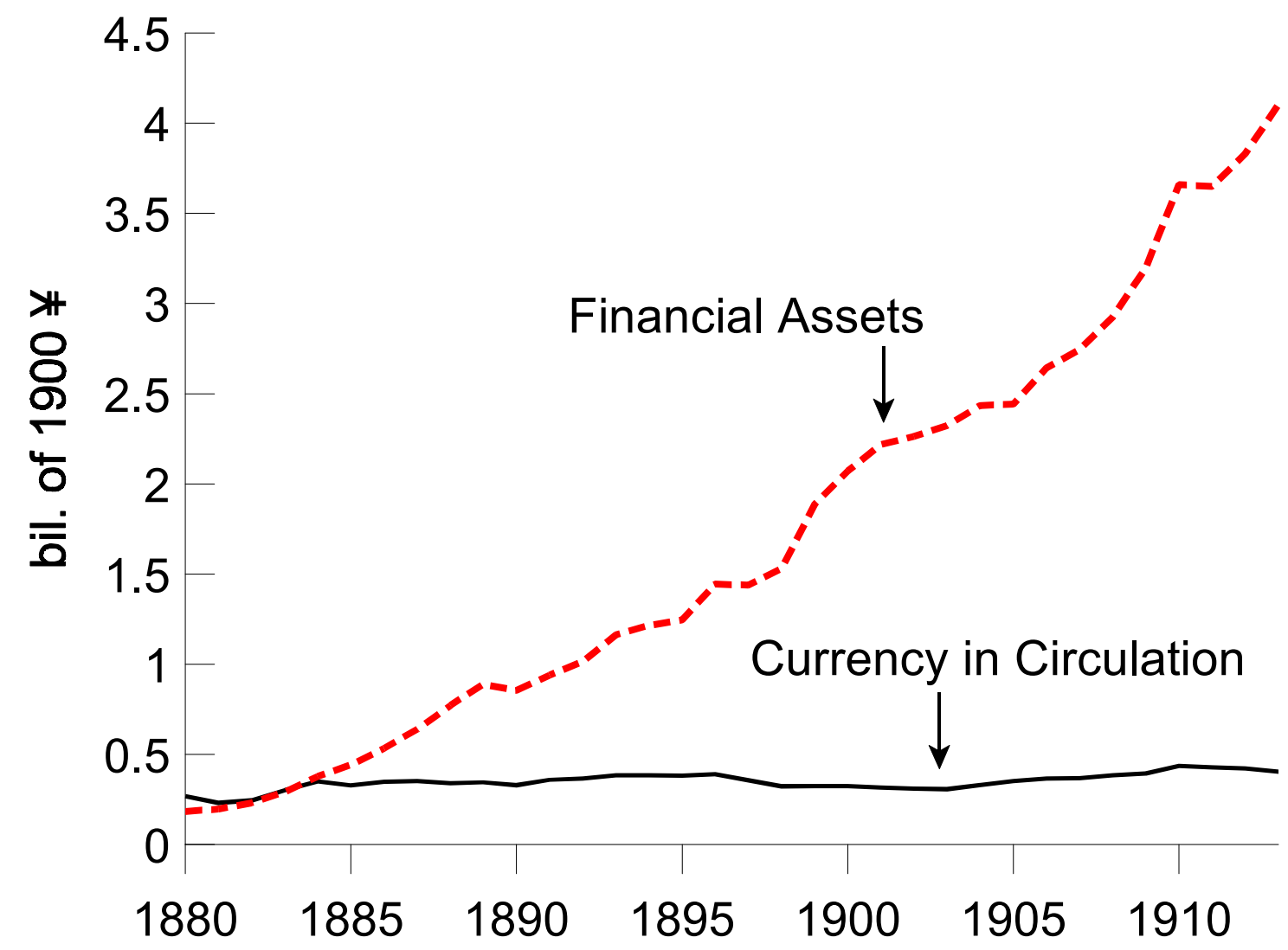

Figure 9. Monetary and Financial Aggregates, Japan 1880-1913.

Figure 9 shows the remarkable growth of the broad financial aggregate from 1880 to 1913, and contrasts it with the relative flatness of the amount of currency in circulation. Gross national product and private domestic fixed investment serve as measures of real sector performance.

The tri-variate VAR specifications that I consider include currency in circulation, the broad financial aggregate, and either output or private fixed investment, with all variables converted to logs of real 1900 quantities prior to analysis. The unit root and cointegration tests for these systems, reported in Tables A.1 and A.2 of the Appendix, suggest that estimation in levels is appropriate. Table 6 presents the results. In the top line of the upper panel, financial assets Granger-cause GNP at the 1 percent level, currency Granger-causes GNP at the 10 percent level, and there is no feedback from output to either currency or financial assets. The lower panel reports qualitatively similar 
Table 6

VARs of financial and real activity, Japan 1880-1913

\begin{tabular}{|c|c|c|c|c|}
\hline Eq. & GNP & $\begin{array}{l}\text { Currency in } \\
\text { circulation }\end{array}$ & $\begin{array}{c}\text { Financial } \\
\text { assets }\end{array}$ & $\begin{array}{c}\text { Adjusted } \\
\mathrm{R}^{2} \\
\end{array}$ \\
\hline $1 \mathrm{a}$ & $\begin{array}{l}-0.163 \\
(0.582)\end{array}$ & $\begin{array}{c}0.097 \\
(0.088)\end{array}$ & $\begin{array}{c}0.360 \\
(0.001)\end{array}$ & 0.988 \\
\hline $1 b$ & $\begin{array}{l}-0.287 \\
(0.576)\end{array}$ & $\begin{array}{c}0.800 \\
(0.000)\end{array}$ & $\begin{array}{c}0.075 \\
(0.286)\end{array}$ & 0.833 \\
\hline $1 \mathrm{c}$ & $\begin{array}{l}-0.170 \\
(0.959)\end{array}$ & $\begin{array}{l}-0.041 \\
(0.875)\end{array}$ & $\begin{array}{c}0.999 \\
(0.000)\end{array}$ & 0.994 \\
\hline Eq. & $\begin{array}{c}\text { Private } \\
\text { Investment } \\
\end{array}$ & $\begin{array}{l}\text { Currency in } \\
\text { circulation }\end{array}$ & $\begin{array}{c}\text { Financial } \\
\text { assets }\end{array}$ & $\begin{array}{c}\text { Adjusted } \\
\mathrm{R}^{2} \\
\end{array}$ \\
\hline $1 \mathrm{a}$ & $\begin{array}{c}0.236 \\
(0.074)\end{array}$ & $\begin{array}{c}1.895 \\
(0.055)\end{array}$ & $\begin{array}{c}0.457 \\
(0.036)\end{array}$ & 0.957 \\
\hline $1 b$ & $\begin{array}{l}-0.138 \\
(0.010)\end{array}$ & $\begin{array}{c}1.060 \\
(0.000)\end{array}$ & $\begin{array}{c}0.087 \\
(0.014)\end{array}$ & 0.872 \\
\hline $1 d$ & $\begin{array}{l}-0.080 \\
(0.616)\end{array}$ & $\begin{array}{c}0.143 \\
(0.585)\end{array}$ & $\begin{array}{c}1.007 \\
(0.000)\end{array}$ & 0.993 \\
\hline
\end{tabular}

NOTE: See note to Table 1. The VAR with GNP uses three lags of each variable, and the VAR with private investment uses four, with the lag orders selected with nested likelihood ratio tests.

findings when private fixed investment replaces output as the measure of real sector activity, except that investment and financial assets now Granger-cause currency. This result reflects a complementarity between cash and real investment, which is consistent with the developingeconomy model introduced by McKinnon (1973, esp. chapter 6). There is again no feedback from investment or currency to financial assets.

The impulse responses Figure 10 indicates that the effects of real financial assets on real output and investment are large, with a 1 percent increase in financial assets associated with a 1.38 percent increase in output (panel b) and a 1.37 percent increase in investment after five years (panel d). It is the effect of currency on investment in panel (c) that is truly striking, with a 1 percent 


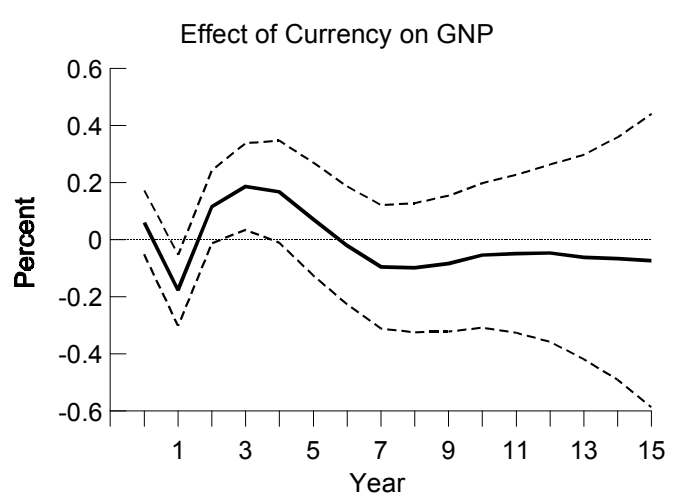

(a)

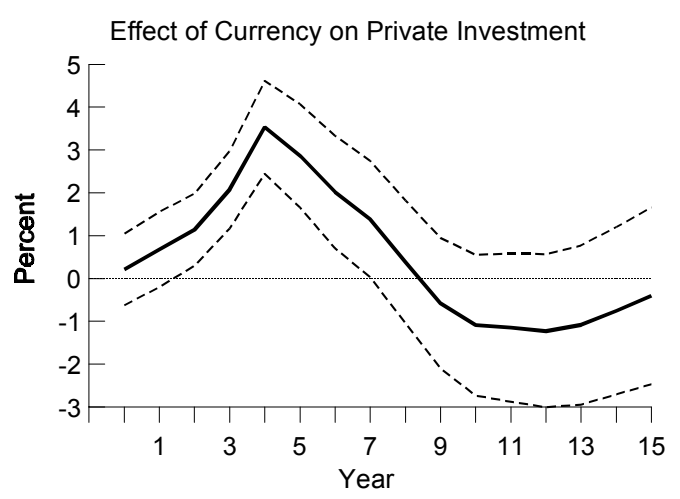

(c)

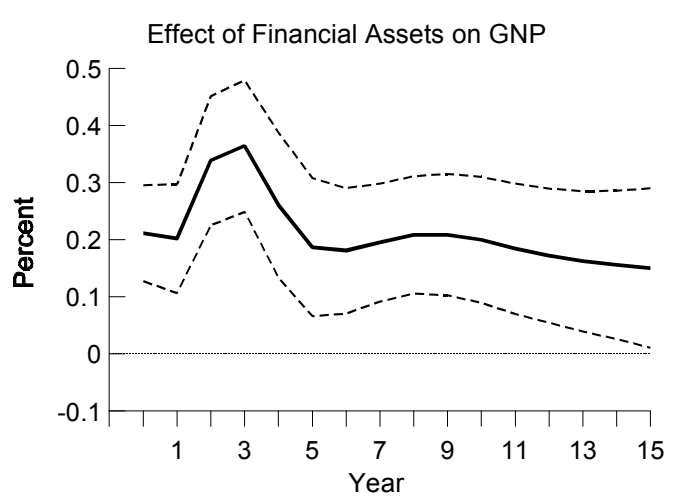

(b)

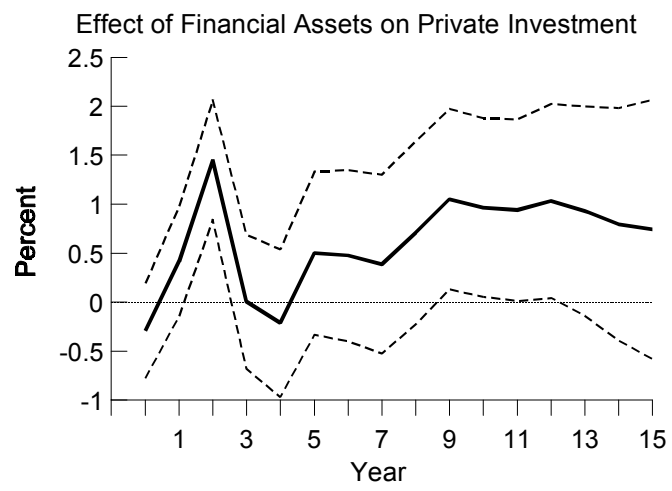

(d)

Figure 10. Selected impulse responses VARs for Japan, 1880-1913.

Note: The impulse responses are taken from the VARs reported in Table 6 . The variable ordering places financial assets first, currency second, and either GNP or private domestic investment third. Using Monte Carlo integration, the solid lines plot the mean impulse responses that result from 10,000 random draws from the distribution of the estimated VAR coefficients. The dotted lines are one standard error bands.

increase in currency raising investment by 7.6 percent after five years. Though strong inferences should surely be avoided given the sheer size of the response and the fact that it was derived from a VAR system with only 34 usable time series observations, the result nonetheless emphasizes that all economic actors did not necessarily have access to the formal financial sector, and may have used cash as a vehicle for saving to overcome investment indivisibilities.

Overall, the findings for Meiji Japan suggest that financial system played a key role in promoting output and investment, and offer strong support for the "finance-led" hypothesis. 


\section{FROM 1850 TO THE PRESENT}

The case approach taken in the previous sections facilitated the statistical investigation of four of history's "financial revolutions" and their impact on real activity, but are indeed limited to countries that achieved some degree of what might be called economic "success." This means that there are elements of selection bias in the cases considered here, not the least of which involves the very availability of early economic data for countries where financial institutions emerged in conjunction with modernization.

This problem is present but less severe after 1850, however, because economic data become available for an increasing number of countries. From 1850 to 1929 , for example, continuous measures of real output and monetization can be assembled for a set of 17 countries that are often referred to as the "Atlantic" economies, even though Australia and Japan is usually included in the group. ${ }^{16}$ This sample is broad enough to consider a cross-section analysis of the relationship between financial deepening and economic growth with the techniques used so successfully for the post World War II period by Ross Levine and his collaborators (e.g., King and Levine, 1993). In this section, I present a few cross-sectional results for the Atlantic economies over the 1850-1997 period, and then compare the findings with those obtained for the subperiod from 1850 to $1930 .{ }^{17}$

The data are from four main sources. From 1960, it is the World Bank's World Development Indicators database. Data for earlier years are from worksheets underlying Bordo and Jonung (2001) and Obstfeld and Taylor (2000), and Mitchell's (1998a, 1998b, 1998c). ${ }^{18}$

\footnotetext{
${ }^{16}$ The seventeen countries are Argentina, Australia, Brazil, Canada, Denmark, Finland, France, Germany, Italy, Japan, the Netherlands, Norway, Portugal, Spain, Sweden, the United Kingdom, and the United States.

${ }^{17}$ The results presented are drawn primarily from Rousseau and Sylla (2001). Interested readers should see this earlier paper for a more extensive analysis.

${ }^{18}$ Rousseau and Sylla (2001, pp. 39-45) include a complete description of the data sources and methods used in constructing this panel.
} 
To examine the partial correlations between the size of the financial sector and economic growth from 1850 while retaining the widest cross section possible, it is necessary to choose a broad aggregate such as the ratio of the liquid liabilities to output as the measure of financial development. Liquid liabilities is of course an imprecise measure because of nonbank intermediaries such as insurance and investment companies whose liabilities do not wind up in the aggregate. These omissions are probably not that important in the prewar period, but quite substantial in recent years. Further, the broadly-defined money stock does not include securities markets. Growth in real income per head, despite its inability to reflect the distribution of wealth and its implications for welfare, is a common measure of economic performance and is readily available for all seventeen countries back into the mid-19th century.

Following the now-standard cross-country growth specification of Barro (1991) as supplemented by King and Levine (1993), Table 7 presents regressions in which the average growth rate of real per capita GDP is the dependent variable. Averaging is done across decades for 18501997 period and across five-year periods for 1850-1929. The baseline regression also conditions on the level of per capita income (in 1960 U.S. dollars) at the start of each period to capture a convergence or "catching up" effect. The ratio of government expenditure to GDP also appears because the resource requirements that are often associated with large public expenditures are likely to "crowd out" private investment and lead to less efficient resource allocations than the private sector might provide. Finally, the ratio of the broad money stock to GDP is included to capture the effects of financial development. The specification also includes dummy variables for each time period to control for time trends in the levels variables and for business cycle effects.

In the OLS regressions, the first observations for each period are used as the regressors to ameliorate the impact of possible reverse causality from growth to additional finance. This technique 
Table 7

Cross-Country Growth Regressions, 1850-1997 and 1850-1929

Dependent variable: \% Growth of per capita real GDP

\begin{tabular}{lcccc} 
& \multicolumn{2}{c}{$1850-1997$} & \multicolumn{2}{c}{$1850-1929$} \\
\cline { 2 - 5 } Constant & OLS & IV & OLS & IV \\
\cline { 2 - 5 } & $7.463^{* *}$ & $6.776^{* *}$ & $6.206^{* *}$ & $6.308^{* *}$ \\
Log of initial real & $(1.500)$ & $(1.477)$ & $(2.034)$ & $(2.050)$ \\
per capita GDP & $-0.706^{* *}$ & $-0.603^{* *}$ & $-0.710^{* *}$ & $-0.731^{* *}$ \\
Initial ratio of broad & $(0.179)$ & $(0.179)$ & $(0.307)$ & $(0.305)$ \\
money to GDP & $0.949^{*}$ & $0.956^{*}$ & $2.251^{* *}$ & $2.186^{* *}$ \\
Initial ratio government & $(0.541)$ & $(0.540)$ & $(1.075)$ & $(1.039)$ \\
expenditure to GDP & $-5.280^{* *}$ & $-5.915^{* *}$ & -6.229 & -6.397 \\
$\mathrm{R}^{2}$ & $(2.299)$ & $(2.583)$ & $(3.848)$ & $(4.150)$ \\
No. observations) & .339 & .372 & .137 & .147 \\
& $(211)$ & $(197)$ & $(186)$ & $(185)$
\end{tabular}

The table reports coefficients from OLS and IV regressions with standard errors in parentheses. The dependent variable is the growth rate of real per capita GDP averaged for each decade for the regressions that cover 1850 to 1997, and averaged over 5-year periods for the regressions that cover 1850 to 1929. Initial values are taken from the first year of each period. Period dummies are included in the regression but are not reported. * and ** denote statistical significance at the 10 percent and 5 percent levels respectively.

cannot fully eliminate the simultaneity problem due to autocorrelation in the time series for financial depth, but it does ensure that all regressors are predetermined and thus plausible determinants of subsequent growth. The IV specifications use contemporaneous averages of the data as regressors and control for simultaneity by instrumenting in each period with the initial values of the complete set of regressors, initial inflation, and the ratio of initial trade (exports plus imports) to GDP.

A strong convergence effect, as indicated by negative coefficients on initial income that are statistically significant at the 5 percent level, is common to all four regressions reported in Table 7. Government expenditure has the expected negative sign and is significant at the 5 percent level for the full 1850-1997 period, but is not quite significant at the 10 percent level for the pre-Depression 
period, though the coefficients are about the same size throughout. The coefficient sizes are robust to the choice of the initial value OLS or IV estimation technique. It is the differences across subperiods in the coefficients on the ratio of the broad money stock, however, that are particularly interesting. For 1850-1997, the coefficient is about 1 and significant at only the 10 percent level. Evaluated at the sample mean of 50.6 percent, this implies that an increase in financial depth of 10 percentage points would increase the annual growth rate of GDP by about 0.1 percent, which is not particularly large. For the $1850-1929$ period, the coefficient is significant at the 5 percent level and more than double the size, implying an increase in GDP growth of 0.22 percent per year for a ten percentage point increase in financial depth from the sample mean of 42.8 percent.

The sharper increase in output for a given change in financial depth in the pre-1930 period is consistent with the view that financial factors matter most emphatically in the early stages of economic development by mobilizing and allocating resources, and make smaller contributions to the efficiency of resource allocation in more mature economies. The sample of "Atlantic" economies makes this point clear, since many were relatively "immature" in the 19th century yet nearly all could be termed "mature" today. King and Levine (1993) obtain results using a similar specification for the post-1960 period that are similar to mine for 1850-1929, and now we can posit at least one reason for this - the King and Levine sample, due to its inclusion of 80 or more countries, captures many of them in their emerging phases, and is thus closer in composition, at least insofar as phases of economic development are concerned, to the earlier sample of Atlantic economies.

\section{CONCLUSION}

The case studies considered in this article offer statistical evidence that the development of banking and securities markets mattered for industrialization and the expansion of commerce in four economies that are generally considered to have experienced "financial revolutions" over the past 
400 years. The data are more limited than those at the disposal of the modern macro economist, and this means that results must be interpreted as more suggestive than definitive, yet the consistency of the evidence with the historical narrative that can be obtained by letting the data speak is unmistakable. Cross-country evidence for the period from 1850 to the present indicates that the results obtained in the case studies are not just a result of biases imposed by the availability of historical data.

Surely other factors, and particularly the adoption of new technologies, are also at the center of commercial and industrial revolutions. In 17th century Amsterdam, that innovation was the ability to build seaworthy vessels quickly and cheaply enough to exploit the trade opportunities associated with circumventing the Cape of Good Hope. For 18th and early 19th century England, it was steam, the power loom and a host of other machines that raised productivity. Even in these cases, however, the new technologies needed financing to get off the ground, and the emerging financial markets in these nations seem to have provided it. And the very availability of financing would have encouraged other potential entrepreneurs to formulate new business ideas.

It is this way that I believe the financial sector mobilized the resources needed to start large projects in the pre-Industrial period and had incentive effects in the real sector that extended beyond those firms that actually received financing. It remained for the later industrial phases, at least in England and the United States, for the financial sector to develop the sophisticated screening and monitoring functions required to affect economic growth through the quality of resource allocations, but the expansion of deposit banking in these countries ultimately did this as well. The process of market emergence and expansion prepared each of the four nations for world economic leadership over the next century - positions that Amsterdam and England were able to retain until new technologies, both real and financial, displaced them in classic episodes of Schumpeterian creative 
destruction. Will today's information technology revolution hasten the emergence of a "world" financial market in which the role of the United States will shift from the heart to a major artery?

\section{REFERENCES}

Bagehot, Walter. Lombard Street: A Description of the Money Market. New York: Scribner, Armstrong \& Co., 1873.

Barro, Robert J. "Economic growth in a cross section of countries." Quarterly Journal of Economics (May 1991) 56 (2), pp. 407 - 443.

Berry, Thomas Senior, "Production and Population Since 1789: Revised GNP Series in Constant Dollars." Bostwick Paper No. 6. Richmond VA: The Bostwick Press, 1988.

Bordo, Michael D., and Lars Jonung. "A Return to the Convertibility Principle? Monetary and Fiscal Regimes in Historical Perspective," in A. Leijonufvud (ed.), Monetary Theory as a Basis for Monetary Policy. London: Macmillan, 2001.

Brainard, William C., and James Tobin. "Pitfalls in Financial Model Building." American Economic Review, May 1968, 58 (2), Papers and Proceedings, pp. 99 - 122.

Bruijn, J. R., F. S. Gaastra, and I. Schoffer. Dutch-Asiatic Shipping in the 17th and 18th Centuries, 3 volumes. The Hague, 1987.

Cameron, Rondo. "England, 1750-1844," in R. Cameron, O. Crisp, H. T. Patrick, and R. Tilly, eds., Banking in the Early Stages of Industrialization: A Study in Comparative Economic History. New York: Oxford University Press, 1967, pp. 15 - 59.

Chaudhuri, K. N. The Trading World of Asia and the English East India Company 1660-1760. Cambridge, UK: Cambridge University Press, 1945.

Clapham, J. H. "The Private Business of the Bank of England, 1744-1800." Economic History Review, February 1941, 11 (1), pp. 77 - 89. 
Clapham, J. H. The Bank of England: A History. New York: Macmillan, 1945.

David, Paul, "The Growth of Real Product in the United States Before 1840: New Evidence, Controlled Conjectures." Journal of Economic History, March 1967, 27 (1), pp. 151 - 197.

Davis, Lance E. "The Investment Market, 1870-1914: The Evolution of a National Market." Journal of Economic History, September 1965, 25 (3), pp. 355 - 399.

de la Vega, Joseph. Confusion de Confusiones, translated by Hermann Kellenbenz. Amsterdam: 1688; reprinted Boston: Harvard Graduate School of Business Administration, 1957.

Dehing, Pit, and Marjolein 't Hart. "Linking the Fortunes: Currency and Banking, 1550-1800," in M. 't Hart, J. Jonker, and J. L. Van Zanden, eds., A Financial History of the Netherlands. Cambridge: Cambridge University Press, 1997, pp. 37 - 63.

Dillen, J. G. van. "Effectenkoersen aan de Amsterdamsche Beurs, 1723-1794." EconomischeHistorische Jaarboek, 1931, 17, pp. 1 - 46.

Dillen, J. G. van. "The Bank of Amsterdam," in J. G. Van Dillen, ed., History of the Public Banks; Accompanied by Extensive Bibliographies of the Histories of Banking and Credit in Eleven European Countries. The Hague: M. Nijhoff, 1934, pp. 79 - 123.

Fazzari, Steven M., R. Glenn Hubbard and Bruce C. Petersen. "Financing Constraints and Corporate Investment." Brookings Papers on Economic Activity, 1988, 1, pp. 141 - 195.

Glamann, Kristof. Dutch-Asiatic Trade, 1620-1740. Copenhagen: The Danish Science Press, 1958.

Goldsmith, Raymond W. The Financial Development of Japan, 1868-1977. New Haven: Yale University Press, 1983.

Greenwood, Jeremy, and Bruce D. Smith. "Financial Markets in Development, and the Development of Financial Markets." Journal of Economic Dynamics and Control, January 1997, 21 (1), pp. 145 $-181$. 
Gurley, John G., and Edward S. Shaw. "Financial Aspects of Economic Development." American Economic Review, September 1955, 45 (3), pp. 515 - 538.

Huffman, Wallace E., and James R. Lothian. "Money in the United Kingdom, 1833-80." Journal of Money, Credit and Banking, May 1980, 12 (1), Part 1, pp. 155 - 174.

Johansen, Soren. "Estimation and Hypothesis Testing of Cointegration Vectors in Gaussian Vector Autoregressive Models." Econometrica, November 1991, 59 (6), pp. 1551 - 1580.

Levine, Ross. "Financial Development and Economic Growth: Views and Agenda." Journal of Economic Literature, 1997, 35, pp. 688 - 726.

Levine, Ross, and Robert G. King. "Finance and Growth: Schumpeter Might Be Right." Quarterly Journal of Economics, August 1997, 108 (3), pp. 717 - 738.

Levine, Ross, and Sara Zervos. "Stock Markets, Banks, and Economic." American Economic Review, June 1998, 88 (3), pp. 537 - 558.

Lockwood, W. W. The Economic Development of Japan: Growth and Structural Change. Princeton: Princeton University Press, 1968.

McKinnon, Ronald I. Money and Capital in Economic Development. Washington DC: The Brookings Institution, 1973.

Mitchell, B. R. British Historical Statistics. Cambridge: Cambridge University Press, 1988.

Mitchell, B. R. International Historical Statistics: Africa, Asia and Oceania, 1750-1993. 4th Edition. New York: Stockton Press, 1998 (a).

Mitchell, B. R. International Historical Statistics: The Americas, 1750-1993. 4th Edition. New York: Stockton Press, 1998 (b).

Mitchell, B. R. International Historical statistics: Europe, 1750-1993. 4th Edition. New York: Stockton Press, 1998 (c). 
Neal, Larry. The Rise of Financial Capitalism: International Capital Markets in the Age of Reason. Cambridge, MA: Cambridge University Press, 1990.

Obstfeld, Maurice, and Alan M. Taylor. Global Capital Markets: Integration, Crises, and Growth. Japan-U.S. Center Sanwa Monographs on International Financial Markets. Cambridge: Cambridge University Press, 2000.

Ohkawa, K., N., M. Shinohara and M. Umemura (eds.), Estimates of Long-Term Economic Statistics of Japan Since 1868, Vols. 1-5. Tokyo: Toyo Keizai Shimposha, 1974.

Osterwald-Lenum, Michael. "A Note with Fractiles of the Asymptotic Distribution of the Maximum Likelihood Cointegration Rank Test Statistics: Four Cases." Oxford Bulletin of Economics and Statistics, August 1992, 54 (4), pp. 461 - 478.

Ott, David J. The financial development of Japan, 1878-1958. Ph.D. dissertation, University of Maryland, 1960.

Richards, R. D. "The First Fifty Years of the Bank of England," in J. G. Van Dillen, ed., History of the Public Banks; Accompanied by Extensive Bibliographies of the Histories of Banking and Credit in Eleven European Countries. The Hague: M. Nijhoff, 1934, pp. 201 - 272.

Rousseau, Peter L. "Finance, Investment, and Growth in Meiji-Era Japan." Japan and the World Economy, April 1999, 11 (2), pp. 185 - 198.

Rousseau, Peter L., and Richard Sylla. "Emerging Financial Markets and Early U.S. Growth." NBER Working Paper No. 7448, December 1999.

Rousseau, Peter L., and Richard Sylla. "Financial Systems, Economic Growth, and Globalization." NBER Working Paper No. 8323, June 2001, and forthcoming in M. Bordo, A. Taylor, and J. Williamson, eds., Globalization in Historical Perspective. Chicago: University of Chicago Press, 2003. 
Rousseau, Peter L., and Paul Wachtel. "Equity Markets and Growth: Cross-Country Evidence on Timing and Outcomes, 1980-1995." Journal of Banking and Finance, December 2000, 24 (12), pp. $1933-1957$.

Rousseau, Peter L., and Paul Wachtel. "Financial Intermediation and Economic Performance:

Historical Evidence From Five Industrialized Countries." Journal of Money, Credit and Banking, November 1998, 30 (4), pp. 657 - 678.

Sims, Christopher A., James H. Stock, and Mark W. Watson. "Inference in Time Series Models With Some Unit Roots.” Econometrica, January 1990, 58 (1), pp. 113 - 144.

Temin, Peter. The Jacksonian Economy. New York: W. W. Norton and Company, 1969.

Sylla, Richard. "Federal Policy, Banking Market Structure, and Capital Mobilization in the United States, 1863-1913." Journal of Economic History, December 1969, 29 (4), pp. 657 - 686.

Sylla, Richard. "U.S. Securities Markets and the Banking System, 1790-1840." Federal Reserve Bank of St. Louis Review, May/June 1998, 80, pp. 83 - 98.

U.S. Bureau of the Census. Historical Statistics of the United States: from Colonial Times to 1970. Washington, DC: Government Printing Office, 1975.

van der Wee, H. The Growth of the Antwerp Market. The Hague: M. Nijhoiff, 1963.

World Development Indicators. Database. Washington, DC: The World Bank, 1999.

Zanden, Jan Luiten van. "What Happened to the Standard of Living Before the Industrial Revolution? New Evidence from the Western Part of the Netherlands." Working Paper, 2000. 


\section{APPENDIX. Time Series Properties of Data Used in the Empirical Analysis}

This section presents Augmented Dickey-Fuller (ADF) tests for unit roots and Johansen (1991) tests for cointegration in the series and VAR systems used in the analysis. If ADF tests are unable to reject the unit root for a series in levels, yet reject after differencing, there is some justification for treating the series as I(1) in subsequent modeling. The univariate representations for the ADF tests include four lags. The trending nature of the series make both constant and trend terms necessary in the levels tests, while a constant-only regression is used for the first differences. The log transformation is applied to series that enter VAR systems as such. Table A.1 reports the test statistics and significance levels.

A VAR system with non-stationary variables is classified as cointegrated if a linear combination exists which yields a stationary series when applied to the data. In the tri-variate case, a cointegrating relationship also implies that the error terms of the system are stationary. The technique developed by Johansen (1991) provides a regression-based test for determining both the presence of cointegration and the number of linear stationary combinations which span the space. Each system is modeled as a VAR of the form

$$
\Delta x_{t}=\mu+\sum_{i=1}^{k-1} \Gamma_{i} \Delta x_{t-i}+\Pi x_{t-k}+e_{t},
$$

where $x_{t}$ is a vector containing the potentially endogenous variables and $k$ is adequately large both to capture the short-run dynamics of the underlying VAR and to generate residuals that approximate the normal distribution. The lag order for each system is chosen with a series of nested likelihood ratio tests. The presence of trends in the data suggest the inclusion of an unrestricted intercept. The Johansen methodology tests whether the $\Pi$ matrix in (B.1) is of less than full rank via the trace and maximum eigenvalue statistics. Table A.2 includes the results and significance levels for the four countries in the study. 
Table A.1

ADF Tests for Series used in the Empirical Analyses

\begin{tabular}{|c|c|c|}
\hline Amsterdam 1641-1794 & Levels & 1st Difference \\
\hline Market value of VOC trade & -2.38 & $-8.60^{* *}$ \\
\hline No. of outbound VOC voyages & $-3.46^{*}$ & $-8.46^{* *}$ \\
\hline VOC hard money exports & -1.89 & $-6.48^{* *}$ \\
\hline BA drawing balances & -2.85 & $-6.36^{* *}$ \\
\hline VOC debt at the BA & -3.41 & $-5.29^{* *}$ \\
\hline \multicolumn{3}{|l|}{ England 1728-1850 } \\
\hline Industrial production & -0.23 & $-4.34^{* *}$ \\
\hline Market value of trade & -0.86 & $-5.94^{* *}$ \\
\hline BE circulation and deposits & -2.15 & $-6.09^{* *}$ \\
\hline BE private loans & -1.41 & $-5.35^{* *}$ \\
\hline EIC exports (1710-1745) & -2.93 & $-3.19^{*}$ \\
\hline EIC debt (1710-1745) & -2.14 & -2.48 \\
\hline EIC cash balances (1710-1745) & -2.52 & $-3.23^{* *}$ \\
\hline EIC Q (1710-1745) & -3.10 & -2.88 \\
\hline \multicolumn{3}{|l|}{ United States, 1790-1850 } \\
\hline Domestic investment & -2.50 & $-4.32^{* *}$ \\
\hline Foreign trade & -2.14 & $-4.39^{*}$ \\
\hline Money stock & -2.38 & $-3.65^{*}$ \\
\hline Number of listed securities & -1.58 & $-3.61^{*}$ \\
\hline \multicolumn{3}{|l|}{ Japan, 1880-1913 } \\
\hline Gross national product & -2.27 & $-6.39^{* *}$ \\
\hline Private domestic investment & -1.94 & $-5.42^{* *}$ \\
\hline Currency in circulation & -2.68 & $-4.67^{* *}$ \\
\hline Financial assets & $-3.80^{* *}$ & $-3.68^{* *}$ \\
\hline
\end{tabular}

In the table, $*$ and $* *$ denote rejection of the unit root hypothesis at the $10 \%$ and $5 \%$ levels. 
Table A.2

Johansen Test Statistics for Cointegration

\begin{tabular}{|c|c|c|c|c|c|c|}
\hline & \multicolumn{2}{|c|}{ Trace } & & \multicolumn{2}{|c|}{ Max. Eigenvalue } & \multirow[b]{2}{*}{$\mathrm{r} \leq 2$} \\
\hline & $\mathrm{r}=0$ & $\mathrm{r} \leq 1$ & & $\mathrm{r}=0$ & $\mathrm{r} \leq 1$ & \\
\hline \multicolumn{7}{|l|}{ Amsterdam $(\mathrm{K}=3)$} \\
\hline trade, BA balances, money exports & $49.19^{* *}$ & $21.38^{* *}$ & & $27.81^{* *}$ & $18.16^{* *}$ & $3.22^{*}$ \\
\hline trade, BA balances, VOC debt & $49.03^{* *}$ & 11.68 & & $37.35^{* *}$ & 9.04 & 2.64 \\
\hline voyages, BA balances, money exports & $55.74^{* *}$ & $27.05^{* *}$ & & $28.69^{* *}$ & $24.20^{* * *}$ & 2.58 \\
\hline voyages, BA balances, VOC debt & $46.90^{* *}$ & $21.12^{* *}$ & & $25.78^{* *}$ & $18.04^{* *}$ & $3.08^{*}$ \\
\hline trade, BA balances, VOC Q & $38.22^{* *}$ & 12.17 & & $26.05^{* *}$ & 11.12 & 1.05 \\
\hline trade, VOC debt, VOC Q & $33.63^{* *}$ & 8.37 & & $25.26^{* *}$ & 7.11 & 1.26 \\
\hline voyages, BA balances, VOC Q & $35.53^{* *}$ & $14.89^{*}$ & & $18.63^{*}$ & $15.95^{* *}$ & 0.94 \\
\hline voyages, VOC debt, VOC Q & $26.92^{*}$ & 8.64 & & 16.29 & 7.36 & 1.27 \\
\hline \multicolumn{7}{|l|}{ England $(\mathrm{K}=3)$} \\
\hline industrial prod., trade, BE liabilities & $30.05^{* *}$ & $14.10^{*}$ & & 15.95 & 13.18 & 0.92 \\
\hline industrial prod., trade, BE loans & $30.97^{* *}$ & 6.04 & & $24.93^{* *}$ & 5.09 & 0.95 \\
\hline EIC trade, EIC debt, EIC Q & $45.01^{* *}$ & $19.37^{* *}$ & & $25.63^{* *}$ & $13.92^{*}$ & $5.45^{* *}$ \\
\hline EIC trade, EIC cash, EIC Q & $41.84^{* *}$ & $20.19^{* *}$ & & $21.65^{* *}$ & $14.39^{* *}$ & $5.81^{* *}$ \\
\hline \multicolumn{7}{|l|}{ United States $(\mathrm{K}=4)$} \\
\hline investment, trade, money & $34.24^{* *}$ & 6.05 & & $28.19^{* *}$ & 5.80 & 0.25 \\
\hline \multirow[t]{2}{*}{ investment, trade, money, \#secs } & $60.23^{* *}$ & 20.93 & 8.76 & $39.30^{* *}$ & 12.17 & 7.83 \\
\hline & $\mathrm{r} \leq 4$ & 0.93 & & & & \\
\hline \multicolumn{7}{|l|}{$\operatorname{Japan}(\mathrm{K}=4)$} \\
\hline GNP, currency, financial assets & $37.77^{* *}$ & 9.01 & & 25.76 & 6.31 & 2.70 \\
\hline investment, currency, financial assets & $48.52^{* *}$ & 9.45 & & $39.07^{* *}$ & 6.20 & 2.70 \\
\hline
\end{tabular}

$\mathrm{K}$ is the lag at which the levels terms enter the test regressions. The columns labeled $\mathrm{r}=0$ test a null hypothesis of no cointegration, while the $r \leq 1(r \leq 2)$ columns test a null of at most one (two) cointegrating vectors. $*$ and $* *$ denote rejections of the null at the $10 \%$ and $5 \%$ levels respectively, with critical values from Osterwald-Lenum (1992), Table 1. 